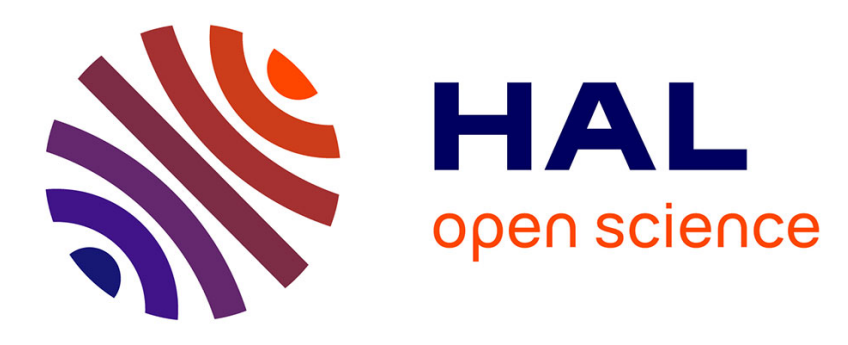

\title{
New 5-ylidene rhodanine derivatives based on the dispacamide A model.
}

Solène Guihéneuf, Ludovic Paquin, François Carreaux, Emilie Durieu, Thierry Roisnel, Laurent Meijer, Jean-Pierre Bazureau

\section{- To cite this version:}

Solène Guihéneuf, Ludovic Paquin, François Carreaux, Emilie Durieu, Thierry Roisnel, et al.. New 5-ylidene rhodanine derivatives based on the dispacamide A model.. Molecular Diversity, 2014, 18 (2), pp.375-88. 10.1007/s11030-014-9509-7 . hal-01017003

HAL Id: hal-01017003 https://hal-univ-rennes1.archives-ouvertes.fr/hal-01017003

Submitted on 1 Jul 2014

HAL is a multi-disciplinary open access archive for the deposit and dissemination of scientific research documents, whether they are published or not. The documents may come from teaching and research institutions in France or abroad, or from public or private research centers.
L'archive ouverte pluridisciplinaire HAL, est destinée au dépôt et à la diffusion de documents scientifiques de niveau recherche, publiés ou non, émanant des établissements d'enseignement et de recherche français ou étrangers, des laboratoires publics ou privés. 


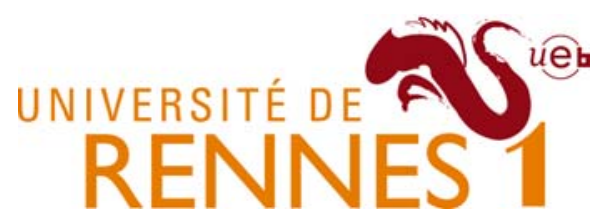

This is the author's final draft post-refeering (post-print)

Find more peer-reviewed articles on our open access repository:

http://hal-univ-rennes1.archives-ouvertes.fr/ 


\section{New 5-ylidene rhodanine derivatives based on the dispacamide A model}

\author{
Solene Guiheneuf • Ludovic Paquin • \\ François Carreaux · Emilie Durieu • Thierry Roisnel • \\ Laurent Meijer · Jean-Pierre Bazureau
}

Keywords Rhodanine - 5-Ylidene rhodanine . Knoevenagel condensation - Microwave condensation . 2-Thioxo-imidazoline-4-one $\cdot$ Kinase

\section{Introduction}

During the two last decades, the 5-arylidene-2-thioxothiazolidine-4-ones and 5-arylidene rhodanine derivatives have been the subject of intensive research by organic chemists and biologists because such compounds represent privileged scaffolds in drug discovery. A survey of recent literature showed that these compounds display a wide range of pharmaceutical properties. For example, epalrestat I (Fig. 1) was used in the treatment of diabetic peripheral neuropathy [1] and has been evaluated as aldose reductase inhibitor [2]. The 5-benzylidene rhodanine core (compound II) has been shown to inhibit the pancreatic cholesterol esterase [3] (CEase). A series of dimeric analogs based on BH3I [4] have been developed as small-molecule Bcl-2 antagonists (compounds III) for apoptosis through a complete SAR study [5]. To discover chemical probes to further understand the function of human DNA polymerase $\lambda$ in cancer by high-throughput screening (HTS) using SYBR Green-based assay [6] and three 5-arylidene-2-thioxo-thiazolidine-4-ones (compounds IV) were identified as potent inhibitors. For Alzheimer's disease, compounds containing the 5-arylidene rhodanine moiety are reported to have an inhibitory effect (compounds V) of tau aggregation [7], amyloid polypeptide fibril formation $[8,9]$, regulation of cathepsin-D immunoreactivity (compound VI) in the senile plaques [10,11]. In addition, rhodanine-based molecules have become a popular small-molecule family of inhibitors for numerus targets in malaria [12,13], Hepatitis C [14], HIV infection [15,16],

ManRos Therapeutics (from Sea to Pharmacy), Hôtel de Recherche, Centre de Perharidy, 29680 Roscoff, France 
<smiles>CC(/C=C1\SC(=S)N(CC(=O)O)C1=O)=C\c1ccccc1</smiles>

I

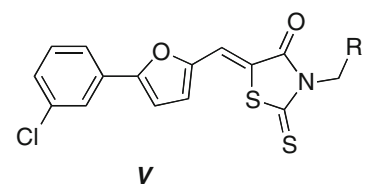<smiles>CCCc1ccccc1NC(=O)[C@H](COCc1ccccc1)NC(=O)c1ccc(/C=C2\SC(=S)NC2=O)cc1</smiles><smiles>[X]c1ccc(/C=C2\SC(=S)N(C(C(=O)O)C(C)C)C2=O)cc1</smiles>
III $(\mathrm{X}=\mathrm{Br}, \mathrm{Cl}, \mathrm{H})$<smiles>[R]c1ccc(Sc2ccc(/C=C3\SC(=S)NC3=O)cc2[R])cc1</smiles>
IV
$\left.\mathrm{R}^{2}=\mathrm{Me}=\mathrm{NO}, \mathrm{F}, \mathrm{Br}\right)$<smiles>O=C(O)CCCCN1C(=O)/C(=C/c2ccc(-c3ccc(-c4ccc(C(=O)O)o4)cc3)o2)SC1=S</smiles><smiles>O=C1NC(Nc2ccccc2)=N/C1=C\c1ccc2c(c1)OCO2</smiles>

Fig. 1 Structures of some bioactive 5-arylidene rhodanine derivatives (I-VI) and leucettine $\mathrm{L}_{41}$ (VII)

Fig. $2 N$-3-substituted 5 -ylidene rhodanine derivatives based on dispacamide A model

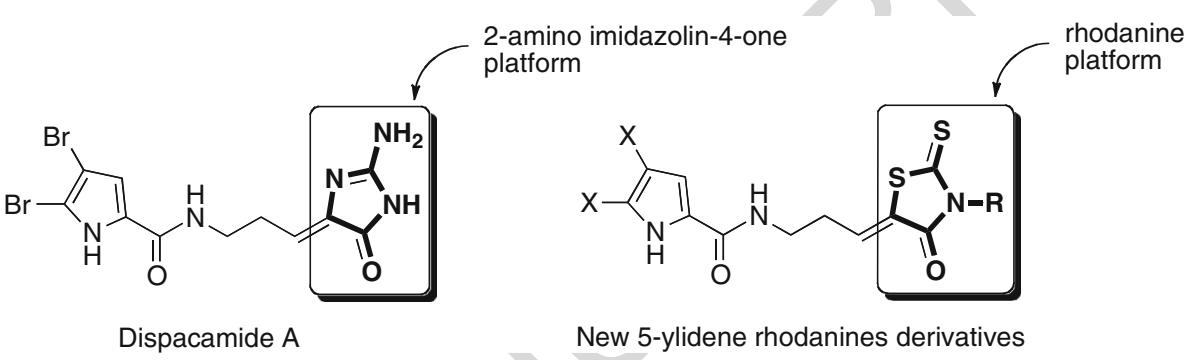

obstructive pulmonary disease and asthma [17], anthrax and botulinum [18].

Our group, during the last 10 years, has investigated the chemical development of analogs of marine sponge alkaloid as inhibitors of protein kinases. Protein kinases represented a class of enzymes, which catalyze protein phosphorylation, a key cellular regulatory mechanism that is frequently deregulated in human diseases. We have recently identified the marine sponge alkaloid leucettamine B as an inhibitor of DYRKs/CLKs [19,20]. The synthesis of analogs of leucettamine B named leucettines (leucettine $L_{41}$ VII) and the biological characterization of leucettines [21] showed that this family of kinase inhibitors deserves futher optimization as potential therapeutics against neurodegenerative diseases such as Alzheimer's diseases [22,23]. In parallel, the 2-amino imidazoline-4-one moiety present in the marine sponge alkaloid dispacamide A (Fig. 1) [24] represented also an attractive scaffold for the search of potential new inhibitor of protein kinases. Recently, we have developed an efficient approach to dispacamide $\mathrm{A}$ and its analogs [25] in seven steps with an overall yield ranging from 12 to $33 \%$. Unfortunately, the preliminary biological screening results of these new dispacamide A derivatives [26] showed moderate inhibition activities against serine/threonine kinases. In our efforts to discover new low molecular weight inhibitors of disease-relevant protein kinases, we focused now our attention on the synthesis of $N$ 3-substituted 5-ylidene rhodanine derivatives based on dispacamide A model (Fig. 2). In this context, the 2-amino- imidazoline-4-one platform of dispacamide A was replaced by a rhodanine platform.

In this approach, the planned retrosynthesis of these 5 -ylidene rhodanine derivatives is based around the key aldol condensation between the $N$-(4,5-dihalogeno pyrrol2-yl) carbamoyl aldehyde building-block and various 2thioxo-thiazolidine-4-ones. This route was envisaged to be amenable to the design of new 5-ylidene rhodanine derivatives for their preliminary screening as kinase inhibitors. Our goal in this study is the development of a convenient, high yielding and robust reaction protocol for the preparation of new $N$-3-substituted 5-yliden-2-thioxo-thiazolidine-4-one derivatives.

\section{Results and discussion}

The overall strategy to the target 5-ylidene $N$-substituted rhodanine derivatives is outlined in Scheme 1. For this study, we have examined the reactivity of various 2-thioxothiazolidine-4-ones $\mathbf{2}(\mathbf{a}-\mathbf{i})$ with the $N$-(4,5-dihalogeno pyrrol-2-yl) carbamoyl aldehydes $\mathbf{1}(\mathbf{a}, \mathbf{b})$ in Knœvenagel condensation under microwave dielectric heating. For the synthesis of small molecules with potential biological activity, the use of microwave irradiation is growing in importance $[27,28]$ because the major benefits of performing reaction under microwave irradiation are higher product yields and shorter reaction times as compared to reactions which run with conventional heating (i.e., in oil bath). A key advan- 


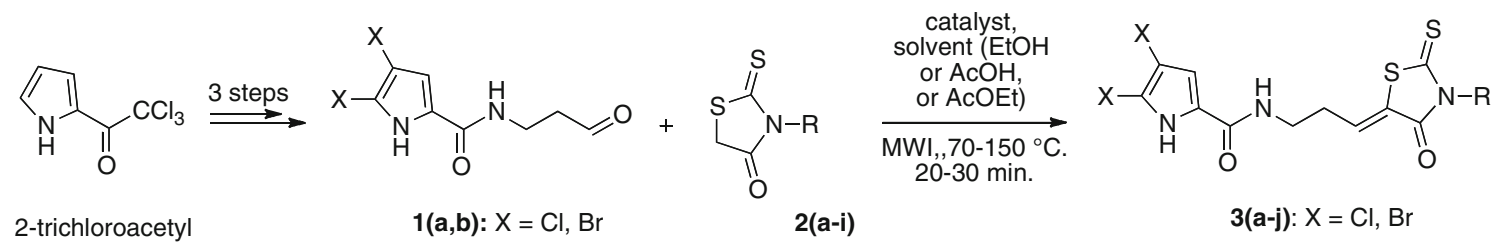
pyrrole
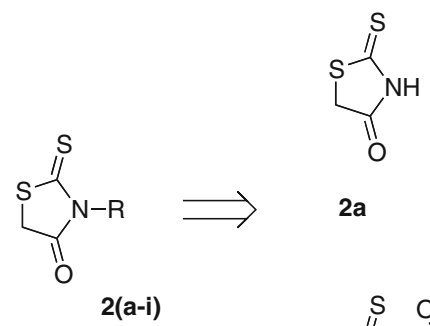<smiles>O=C(O)CN1C(=O)CSC1=S</smiles><smiles>O=C(O)CCN1C(=O)CSC1=S</smiles><smiles>NN1C(=O)CSC1=S</smiles><smiles>O=C1CSC(=S)N1NS(=O)(=O)c1ccccc1</smiles>

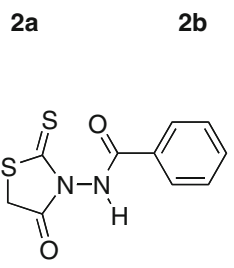

2f

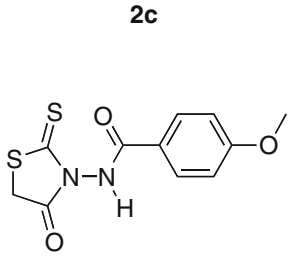

$2 \mathrm{~g}$

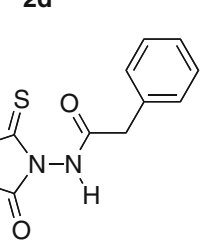

$2 \mathrm{~h}$
$2 e$

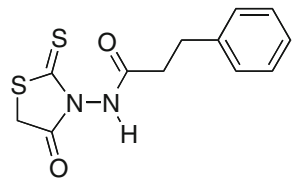

2i

Scheme 1 General synthetic approach for 5-ylidene rhodanines derivatives $\mathbf{3}(\mathbf{a}-\mathbf{j})$ and structure of the starting rhodanines $\mathbf{2}(\mathbf{a}-\mathbf{i})$

Scheme 2 Synthetic approach used for the preparation of $N$-substituted rhodanines $\mathbf{2 c}$, 2(e-i)

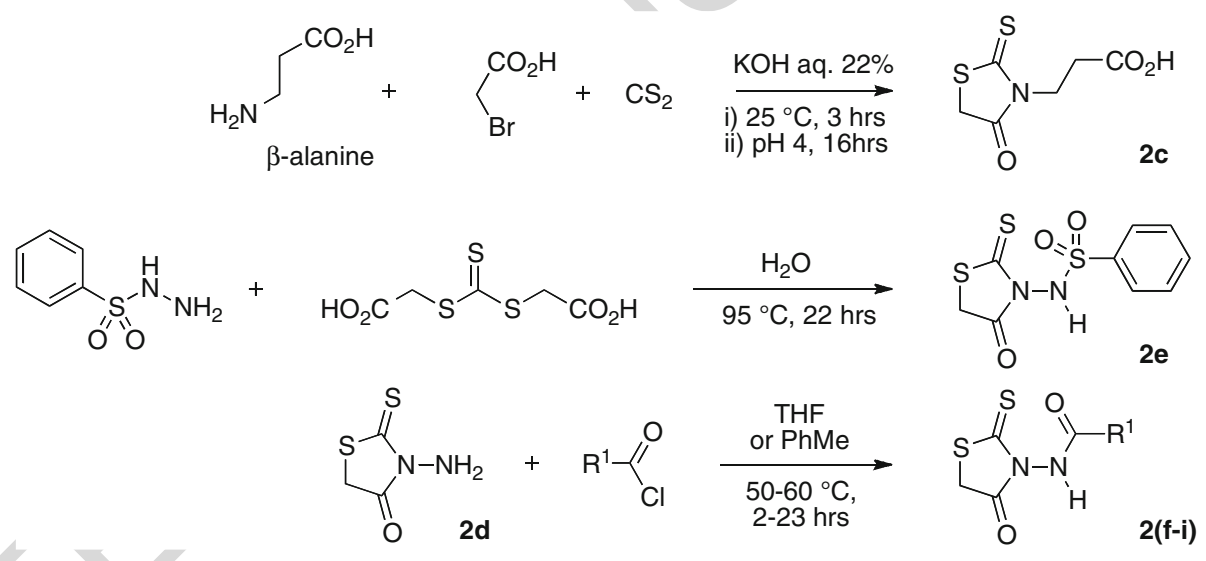

tage of modern commercial scientific laboratory microwave apparatus is their ability to control reaction conditions precisely, by monitoring temperature/pressure, and reaction times.

The $N$-(4,5-dihalogeno pyrrol-2-yl) carbamoyl aldehyde partners 1(a,b) were prepared in three steps according to our previously published method [24]. Starting from commercial readily available 2-trichloroacetyl pyrrole, a regioselective halogenation was conducted by addition of bromine $(\mathrm{X}=\mathrm{Br})$ or sulfuryl chloride $(\mathrm{X}=\mathrm{Cl})$ to give the corresponding $\mathrm{C}-4$, C-5 dihalogeno pyrroles (70-90\%), which were then coupled with 3,3-diethoxy-1-aminopropane (75-88\%). The corresponding $N$-(4,5-dihalogenopyrrol-2-yl) carbamoyl acetals were deprotected with p-TsOH at $55^{\circ} \mathrm{C}$ after $6 \mathrm{~h}(98 \%)$ and led to the aldehyde building-blocks $\mathbf{1}(\mathbf{a}, \mathbf{b})$ in good overall yields (1a $60 \%$ for $\mathrm{X}=\mathrm{Br}$; $1 \mathbf{b} 66 \%$ for $\mathrm{X}=\mathrm{Cl}$ ).

For the present study, we have investigated the chemical reactivity of a series of various $N$-substituted rhodanines $\mathbf{2}(\mathbf{a}-\mathbf{i})$ for Knoevenagel condensation in the presence of alde- hydes $\mathbf{1}(\mathbf{a}, \mathbf{b})$. Among these compounds, rhodanine $\mathbf{2 a}, 2$ (4-oxo-2-thioxo-thiazolidin-3-yl)acetic acid $\mathbf{2 b}$ and 3 -amino rhodanine $\mathbf{2 d}$ are commercially available. Access to 3-(4oxo-2-thioxo-thiazolidin-3-yl)propanoic acid 2c (Scheme 2) could be accomplished by the reaction of $\beta$-alanine with carbon disulfide and bromoacetic acid in aqueous potassium hydroxide [29]. After $3 \mathrm{~h}$ at room temperature, the reaction mixture was acidified at $\mathrm{pH} 4$ and the desired insoluble compound 2c was obtained in $44 \%$ yield (Table 1) by simple filtration. To introduce the arylsulfonamide functionality on the rhodanine moiety in compound $\mathbf{2 e}$, we used the Power's approach [14]: firstly, the formation of the arylsulfonyl hydrazide was accomplished by treatment of sulfonyl chloride at $0{ }^{\circ} \mathrm{C}$ with hydrazine in THF followed by aqueous work-up and, secondly, the arylsulfonyl hydrazide treated with bis-(carbomethyl)trithiocarbonate [30,31] in water at $95{ }^{\circ} \mathrm{C}$ for $22 \mathrm{~h}$ produced 3-(arylsulfonylamino)rhodanine $\mathbf{2 e}$ in $41 \%$ yield after purification by crystallization from ethanol. 
Table 1 Results for the preparation of $N$-substituted rhodanines $\mathbf{2 c}, \mathbf{2}(\mathbf{e}-\mathbf{i})$

Compound Structure

${ }^{a}$ Isolated yields after purification

Next, the preparation of compounds $\mathbf{2}(\mathbf{f}-\mathbf{i})$ involved the use of commercial 3-amino rhodanine $\mathbf{2 d}$ as starting product. Among the conditions studied, we found that reaction of $\mathbf{2 d}$ with benzoyl chloride in THF at $60^{\circ} \mathrm{C}$ gave good conversion to $\mathbf{2 f}(90 \%)$ after $2 \mathrm{~h}$. For compounds $\mathbf{2}(\mathbf{g}-\mathbf{i})$, optimal reaction conditions were obtained only in dry toluene at $50{ }^{\circ} \mathrm{C}$. After a reaction time ranging from 8 (for $\mathbf{2 g}, \mathbf{h}$ ) to $23 \mathrm{~h}$ (for $\mathbf{2 i}$ ) which were monitored by thin-layer chromatography on silica gel using dichloromethane/ethanol (9:1) as eluent, we obtained the crystallized compounds $2(\mathbf{g}-\mathbf{i})$ in good to high yields (84-98\%). With the desired $N$-substituted rhodanines $2(\mathbf{a}-\mathbf{i})$ and the $N$-(4,5-dihalogeno pyrrol-2-yl)carbamoyl aldehydes $\mathbf{1}(\mathbf{a}, \mathbf{b})$ in hand, we proceeded to examine the Knoevenagel condensation under microwave dielectric heating for the synthesis of new 5 -ylidene rhodanines $\mathbf{3}(\mathbf{a}-\mathbf{j})$ based on the dispacamide A model. In literature, the condensation of an aryl aldehyde to 2-thioxo-thiazolidine-4-one required the presence of a base such as piperidine in ethanol [32,33], piperidine/AcOH in ethanol under microwave irradiation [34-37] or with a catalytic amount of piperidinium acetate in refluxing toluene [38], AcONa in refluxed $\mathrm{AcOH}[39,40]$ or concentrated ammonia solution in the presence of $\mathrm{NH}_{4} \mathrm{Cl}$ [41]. The use of solventless reaction conditions has also been employed with task specific ionic liquids (TSILs) [42,43] or with a solid inorganic support $\left(\mathrm{Al}_{2} \mathrm{O}_{3}\right.$ or KSF) under microwave [44]. In this context, we decided to perform the condensation reaction under microwave dielectric heating and we screened a range of reaction parameters in order to find optimal reaction conditions. Reaction optimization for the synthesis of compounds $3(\mathbf{a}-\mathbf{j})$ consisted of varying the reaction temperature $\left(70-150{ }^{\circ} \mathrm{C}\right)$, the irradiation power $(50-200 \mathrm{~W})$, the reaction time (20-40 min), the nature of the solvent (EtOH, $\mathrm{AcOH}$, or
$\mathrm{AcOEt}$ ), the base (piperidine, $\mathrm{Et}_{3} \mathrm{~N}$ or $\mathrm{AcONa}$ ) and the ratio of rhodanine 2 with the base. The reactions were conducted in borosilicate vials of $10 \mathrm{~mL}$ equipped with snap caps (at the end of the irradiation reaction time, cooling was realized automatically by compressed air). As shown in Table 2, the use of 0.1 equivalent of piperidine/ $\mathrm{AcOH}$ in ethanol has been employed for the synthesis of $N$-3-substituted 5-ylidene rhodanine derivatives $\mathbf{3}(\mathbf{a}-\mathbf{c})$ and $\mathbf{3 f}$ in poor (3f $19 \%)$, moderate (3c $46 \%$ ) to good yields (3a $88 \%$ and $3 \mathbf{b} 82 \%$ ). In contrast, any effort to obtain Knoevenagel condensation adducts from the reaction of the other $N$-substituted rhodanines 2 with aldehydes $\mathbf{1}(\mathbf{a}, \mathbf{b})$ was unsuccessful using these reaction conditions. This implies that new specific synthetic protocols has to be devised for the others products 3 . Finally, treatment of $\mathbf{1}$ and $\mathbf{2}$ with a stoichiometric mixture of $\mathrm{AcONa} / \mathrm{AcOH}$ ( 1 equivalent) during $20 \mathrm{~min}$ at $120-140{ }^{\circ} \mathrm{C}$ afforded the compounds $\mathbf{3 d}$ and $\mathbf{3}(\mathbf{g}-\mathbf{j})$ in yields ranging from 46 to $74 \%$. It is noteworthy that access to compound $\mathbf{3 e}$ required the use of triethylamine (TEA) in glacial acetic acid instead of piperidine or AcONa and the condensation reaction was conducted in ethyl acetate (AcOEt). Compound $\mathbf{3 e}$ was synthesized in $71 \%$ yield after a reaction time of 30 min using moderate reaction temperature $\left(70^{\circ} \mathrm{C}\right)$ and irradiation power $(50 \mathrm{~W})$ in a glass vial without snap caps (or in open vessel at atmospheric pressure).

Structures of the desired compounds $\mathbf{3}(\mathbf{a}-\mathbf{j})$ were substantiated by ${ }^{1} \mathrm{H},{ }^{13} \mathrm{C}$ NMR and HRMS analyses. In theory, $E$ and $Z$ geometrical isomers around the exocyclic double $(\mathrm{CH}=\mathrm{C})$ are possible for the $N$-3-substituted 5-ylidene rhodanine derivatives $\mathbf{3}(\mathbf{a}-\mathbf{j}) .{ }^{1} \mathrm{H}$ NMR spectra of these compounds 3 show only one signal for the methylene proton $(\mathrm{CH}=)$ in the range of $6.82-7.20 \mathrm{ppm}$, at lower field val- 
Table 2 Results for the preparation of $N$-3-substituted 5-ylidene rhodanine derivatives $\mathbf{3}(\mathbf{a}-\mathbf{j})$ from $N$-substituted rhodanines $\mathbf{2}(\mathbf{a}-\mathbf{i})$ and 4,5 dihalogeno-1 $H$-pyrrole-2-carboxylic acid (3-oxopropyl)-amide $\mathbf{1}(\mathbf{a}, \mathbf{b})$

\begin{tabular}{|c|c|c|c|c|c|c|c|}
\hline \multirow[t]{2}{*}{ Compound } & \multirow{2}{*}{$\begin{array}{l}\text { Structure of } \\
\text { compound } 3\end{array}$} & \multicolumn{5}{|c|}{ Reaction conditions used under microwave ${ }^{\mathrm{a}}$} & \multirow[t]{2}{*}{ Yield $^{\mathrm{b}}(\%)$} \\
\hline & & Reagents & $\begin{array}{l}\text { Solvent } \\
\text { reaction }\end{array}$ & $\begin{array}{l}\text { Reac. temp. } \\
\left({ }^{\circ} \mathrm{C}\right)\end{array}$ & $\begin{array}{l}\text { Reac. time } \\
\text { (min) }\end{array}$ & $\begin{array}{l}\text { Power } \\
\text { (W) }\end{array}$ & \\
\hline $3 \mathbf{a}$ & & piperidine/AcOH (0.1 eq.) & $\mathrm{EtOH}$ & 150 & 20 & $200^{c}$ & 88 \\
\hline $3 \mathbf{b}$ & & piperidine/AcOH (0.1 eq.) & $\mathrm{EtOH}$ & 150 & 20 & $200^{\mathrm{c}}$ & 82 \\
\hline $3 \mathrm{c}$ & $\mathrm{Br}$ & piperidine/AcOH (0.1 eq.) & $\mathrm{EtOH}$ & 110 & 40 & $-{ }^{d}$ & 46 \\
\hline 3d & $\mathrm{Br}$ & $\mathrm{AcONa} / \mathrm{AcOH} 1$ eq. & $\mathrm{AcOH}$ & 140 & 20 & $60^{c}$ & 46 \\
\hline $3 \mathbf{e}$ & $\mathrm{Br}$ & $\mathrm{Et}_{3} \mathrm{~N} / \mathrm{AcOH}(0.1$ eq. $)$ & AcOEt & 70 & 30 & $50^{\mathrm{c}, \mathrm{e}}$ & 71 \\
\hline $3 f$ & $\mathrm{Br}$ & piperidine $/ \mathrm{AcOH}$ (0.1 eq.) & $\mathrm{EtOH}$ & 150 & 20 & $-{ }^{\mathrm{d}}$ & 19 \\
\hline $3 \mathbf{g}$ & & $\mathrm{AcONa} / \mathrm{AcOH}$ (1 eq.) & $\mathrm{AcOH}$ & 120 & 20 & $100^{\mathrm{c}}$ & 52 \\
\hline $3 \mathbf{h}$ & & $\mathrm{AcONa} / \mathrm{AcOH}$ (1 eq.) & $\mathrm{AcOH}$ & 120 & 20 & $100^{\mathrm{c}}$ & 74 \\
\hline $3 \mathbf{i}$ & & $\mathrm{AcONa} / \mathrm{AcOH}$ (1 eq. $)$ & $\mathrm{AcOH}$ & 120 & 20 & $100^{\mathrm{c}}$ & 58 \\
\hline $3 \mathbf{j}$ & & $\mathrm{AcONa} / \mathrm{AcOH}$ (1 eq.) & $\mathrm{AcOH}$ & 120 & 20 & $100^{c}$ & 49 \\
\hline
\end{tabular}

${ }^{a}$ Microwave irradiation of the reaction mixture was realized in a glass tube sealed with a snap cap (closed vessel)

${ }^{\mathrm{b}}$ Isolated yield after workup and purification by preparative chromatography (on a Combi Flash $R_{f} 200$ psi, Serlabo Technologies France using pre-packed column of silica gel 60 F 254 Merck equipped with a DAD UV/Vis 200-360 nm detector) unless indicated otherwise

${ }^{\mathrm{c}}$ Explorer®24 (CEM France) used as microwave reactor

${ }^{\mathrm{d}}$ Monowave ${ }^{\circledR} 300$ (Anton Paar France) used as microwave reactor

e The reaction was conducted in glass tube without snap cap (open vessel mode)

ues than those expected for the $E$-isomers, which strongly indicates that the compounds have the $Z$-configuration. The $Z$-configuration of compounds $\mathbf{3}(\mathbf{a}-\mathbf{j})$ was confirmed from the ${ }^{1} \mathrm{H}$-coupled ${ }^{13} \mathrm{C}$ NMR spectrum of these compounds followed by examination of the splitting pattern and coupling constant of the signal of the $\mathrm{C}=\mathrm{O}$ group in the rhodanine sys- 
Fig. 3 Ortep diagram of 4,5-dibromo- $1 \mathrm{H}$-pyrrol-2carboxylic acid [3-(4-oxo-2-thioxo-thiazolidin5-ylidene)-propyl]-amide 3a obtained by X-ray diffraction<smiles>O=C1NC(=S)S/C1=C\CCNC(=O)c1cc(Br)c(Br)[nH]1</smiles>

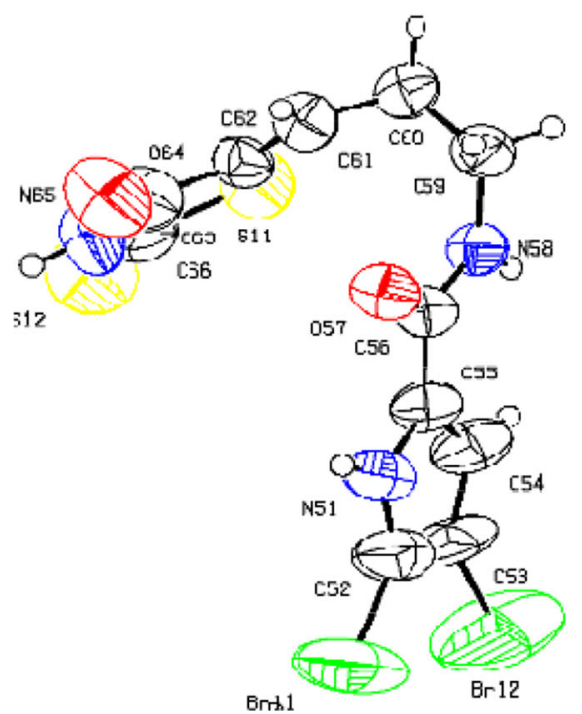

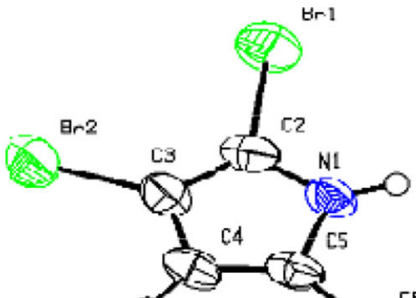

07
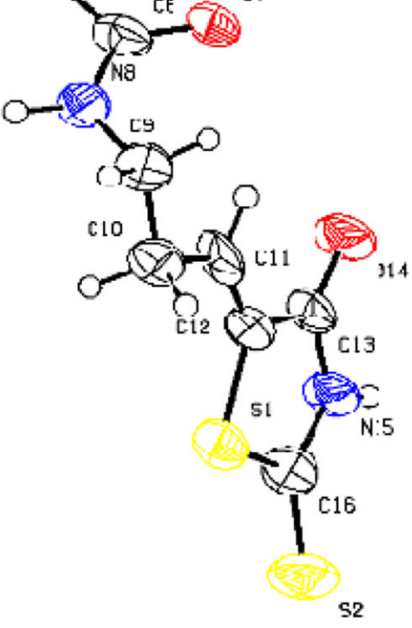

Table 3 Effects of compounds $\mathbf{3}(\mathbf{a}-\mathbf{j})$ on the catalytic activity of eight purified protein kinases ${ }^{\mathrm{a}}$

\begin{tabular}{|c|c|c|c|c|c|c|c|}
\hline Compound & CDK1 & CDK2 & CDK5/p25 & GSK $3 \alpha / \beta$ & CK1 & DYRK1A & CLK1 \\
\hline Dispacamide A & - & - & - & $>10$ & - & $>10$ & - \\
\hline $3 \mathbf{a}$ & $>10$ & $>10$ & $>10$ & - & - & 5.7 & - \\
\hline $3 \mathbf{b}$ & $>10$ & $>10$ & $>10$ & $>10$ & $>10$ & $>10$ & $>10$ \\
\hline $3(\mathbf{c}-\mathbf{j})$ & - & - & & - & - & - & - \\
\hline
\end{tabular}

a Compounds were tested at various concentrations on each kinase as described in "Experimental" section. $\mathrm{IC}_{50}$ values are reported in $\mu \mathrm{M},-$ inactive at the highest concentration tested $(10 \mu \mathrm{M}) ;>10$ inhibitory but $\mathrm{IC}_{50}>10 \mu \mathrm{M}$

tem [45]. Finally, the $Z$-configuration and also the chemical structure of 3 were confirmed by the single X-ray diffraction analysis of 4,5-dibromo- $1 \mathrm{H}$-pyrrol-2-carboxylic acid [3-(4-oxo-2-thioxo-thiazolidin-5-ylidene)-propyl]-amide 3a (Fig. 3).

As an initial effort to investigate their in vitro bioactivity, the new 5-ylidene rhodanine derivatives $\mathbf{3}(\mathbf{a}-\mathbf{j})$ were tested against three protein kinases relevant to Alzheimer's disease, CK $1 \alpha / \beta$ (casein kinase $1 \alpha / \beta$ ), CDK5 (cyclin-dependent kinase 5$) / \mathrm{p} 25$ and GSK-3 $\alpha / \beta$ glycogen synthase kinase $3 \alpha / \beta$. All assays were run in the presence of $15 \mu \mathrm{M}$ ATP and appropriate protein substrates (RRKHAAIGpSAYSITA peptide for $\mathrm{CK} 1 \alpha / \beta$, histone $\mathrm{H} 1$ for $\mathrm{CDK} 5 / \mathrm{p} 25$, GS1 (YRRAAVPPSPSLSRHSSPHQSpEDEEE) peptide for GSK-3 $\alpha / \beta)$. $\mathrm{IC}_{50}$ values were determined from doseresponse curves and are provided in Table 3.

These results are summarized in Table 3. The unsubstituted compound 3a showed promising inhibitory activity against DYRK1A with $\mathrm{IC}_{50}$ value in the single-digit micro- molar range (3a: $\left.\mathrm{IC}_{50} 5.7 \mu \mathrm{M}\right)$. Yet the other new 5-ylidene rhodanine derivatives $\mathbf{3}(\mathbf{c}-\mathbf{j})$ substituted in position $N-3$ were considered inactive on CDKs, GSK $3 \alpha / \beta, \mathrm{CK} 1, \mathrm{CLK} 1$ and DYRK1A since they displayed $\mathrm{IC}_{50}$ values above $10 \mu \mathrm{M}$, these results suggested that these structures cannot be accommodated in the ATP binding site of these protein kinases by hydrogen bond interactions with specific amino-acids of the ATP-binding pocket of each protein kinase.

\section{Conclusion}

In summary, the present study described a practical approach to new 5-ylidene rhodanine derivatives $\mathbf{3}(\mathbf{a}-\mathbf{j})$ bearing the (4,5-dihalogeno-pyrrol-2-yl)carbamoyl fragment of dispacamide $\mathrm{A}$ as potential inhibitors of protein kinases for therapeutics against neurodegenerative diseases. The key step of this solution phase organic synthesis involved a Knoevenagel condensation under microwave dielectric heat- 
ing from $N$-(4,5-dihalogeno-pyrrol-2-yl) carbamoyl aldehydes $\mathbf{1}(\mathbf{a}, \mathbf{b})$ and $N$-substituted rhodanines $\mathbf{2}(\mathbf{a}-\mathbf{i})$ partners. This microwave-assisted condensation afforded new (5Z) 5ylidene rhodanines derivatives in a stereo-controlled fashion with yields ranging from 19 to $88 \%$ and in high purity after purification by preparative chromatography on silica gel. This work should enable further biological evaluations, new analogs though the simple synthetic process described here, and further studies towards a complete structure-activity relationship (SAR). These studies are on going in our laboratory.

\section{Chemistry experimental part}

Melting points were determined on a Kofler melting point apparatus and were uncorrected. Thin-layer chromatography (TLC) was accomplished on 0.2-mm precoated plates of silica gel 60 F-254 (Merck). Visualization was made with ultraviolet light (254 and $365 \mathrm{~nm}$ ) or with a fluorescence indicator. ${ }^{1} \mathrm{H}$ NMR spectra were recorded on BRUKER AC $300 \mathrm{P}$ (300 MHz) spectrometer, ${ }^{13} \mathrm{C}$ NMR spectra on BRUKER AC $300 \mathrm{P}(75 \mathrm{MHz})$ spectrometer. Chemical shifts are expressed in parts per million downfield from tetramethylsilane as an internal standard. Data are given in the following order: $\delta$ value, multiplicity (s, singlet; d, doublet; t, triplet; q, quartet; m, multiplet; br, broad), number of protons, coupling constants $J$ is given in Hz. The mass spectra (HRMS) were taken respectively on a MS/MS ZABSpec Tof Micromass (EBE TOF geometry) at an ionizing potential of $8 \mathrm{eV}$ and on a VARIAN MAT 311 at an ionizing potential of $70 \mathrm{eV}$ in the "Centre Régional de Mesures Physiques de l'Ouest" (CRMPO, Rennes). Reactions under microwave irradiations were realized in the Explorer®24 CEM microwave reactor (CEM France) and also in the Anton Paar Monowave $300 \circledR$ microwave reactor (Anton Paar France) using borosilicate glass vials of $10 \mathrm{~mL}$ equipped with snap caps (at the end of the irradiation, cooling reaction was realized by compressed air). The microwave instrument consists of a continuous focused microwave power output from 0 to $300 \mathrm{~W}$ for the Explorer ${ }^{\circledR} 24$ CEM apparatus and from 0 to $800 \mathrm{~W}$ for the Anton Paar Monowave 300®apparatus. All the experiments were performed using stirring option. The target temperature was reached with a ramp of $2 \mathrm{~min}$ and the chosen microwave power stay constant to hold the mixture at this temperature. The reaction temperature is monitored using calibrated infrared sensor and the reaction time included the ramp period. The microwave irradiation parameters (power and temperature) were monitored by the ChemDriver software package for the Explorer ${ }^{\circledR} 24$ CEM apparatus and by the Monowave software package for the Anton Paar Monowave 300®reactor. Preparative chromatographies were realized on a Combi Flash $R_{f} 200$ psi (Serlabo Technologies France) using pre-packed column of silica gel 60 F 254 Merck equipped with a DAD UV/Vis 200-360 nm detector. Elemental analyses were performed on a Flash Microanalyzer EA1112 CHNS/O Thermo Electron in the "Centre Régional de Mesures Physiques de l'Ouest" (CRMPO, Rennes). Solvents were evaporated with a BUCHI rotary evaporator. All reagents and solvents were purchased from Acros, Aldrich Chimie, and Fluka France and were used without further purification. The starting aldehydes 4,5-dibromo-1 $H$-pyrrole-2-carboxylic acid (3-oxo-propyl)amide 1a and 4,5-dichloro- $1 H$-pyrrole-2-carboxylic acid (3oxo-propyl)-amide $\mathbf{1 b}$ were synthesized according to our previous methods described in literature [19].

\section{3-(4-Oxo-2-thioxo-thiazolidin-3-yl)-propionic acid (2c)}

In a $25 \mathrm{~mL}$ two-necked round-bottomed flask provided with a magnetic stirrer and condenser, $\beta$-alanine $(500 \mathrm{mg}$, $5.61 \mathrm{mmol}$ ) was solubilized in a solution of $22 \%$ potassium hydroxide at room temperature. To this homogeneous solution was added carbon disulfide $(0.37 \mathrm{~mL}, 6.12 \mathrm{mmol})$ dropwise during $10 \mathrm{~min}$ at $25^{\circ} \mathrm{C}$. After stirring over a period of $3 \mathrm{~h}$, commercial bromoacetic acid $(781 \mathrm{mg}, 5.61 \mathrm{mmol})$ was added in small portions to the reaction mixture. The yellowish solution was vigorously stirred at $25{ }^{\circ} \mathrm{C}$ during $3 \mathrm{~h}$. The resulting orange solution was acidified at $\mathrm{pH} 4$ with conc sulfuric acid then, stirred over a period of $16 \mathrm{~h}$ and orange needles appeared in the suspension. The insoluble product $2 \mathbf{c}$ was collected by filtration and dried under high vacuum $\left(10^{-2}\right.$ Torr) at $25^{\circ} \mathrm{C}$ for $2 \mathrm{~h}$. The product $2 \mathrm{c}$ (503 mg, $44 \%$ yield) was further used without purification. $\mathrm{Mp}=162-164{ }^{\circ} \mathrm{C} .{ }^{1} \mathrm{H}$ NMR (DMSO- $\left.d_{6}\right) \delta: 4.05(\mathrm{~m}, 4 \mathrm{H}$, $\mathrm{H}-3, \mathrm{C}_{2}$ ); 4.22 (s, 2H, H-5, $\mathrm{C}_{2}$ ). ${ }^{13} \mathrm{C}$ NMR (DMSO$\left.d_{6}\right) \delta: 30.57\left(\mathrm{C}-2, \underline{\mathrm{CH}_{2} \mathrm{CO}}\right) ; 35.90\left(\mathrm{C}-3, \mathrm{NCH}_{2}\right) ; 39.57(\mathrm{C}-$

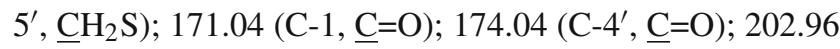
(C-2', $\mathrm{C}=\mathrm{S}$ ). HRMS, $m / z: 249.9585$ found (calculated for $\mathrm{C}_{6} \mathrm{H}_{6} \mathrm{NO}_{3} \mathrm{Na}_{2} \mathrm{~S}_{2}[\mathrm{M}-\mathrm{H}+2 \mathrm{Na}]^{+}$requires 249.9585).

\section{$N$-(4-Oxo-2-thioxo-thiazolidin-3-yl)-benzenesulfonamide} (2e)

In a $25 \mathrm{~mL}$ two-necked round-bottomed flask provided with a magnetic stirrer and condenser, a suspension of commercial phenylsulfonyl hydrazine ( $500 \mathrm{mg}, 2.9 \mathrm{mmol}$ ) in $3 \mathrm{~mL}$ of deionized water was vigorously stirred at $95^{\circ} \mathrm{C}$ during $2 \mathrm{~h}$ and produced an homogeneous yellow solution. To this solution was added commercial bis-(carboxymethyl)trithiocarbonate (657 mg, $2.9 \mathrm{mmol})$. The reaction mixture was stirred at $95^{\circ} \mathrm{C}$ over a period of $22 \mathrm{~h}$. Water was evaporated in vacuo during $7 \mathrm{~h}$ and the desired insoluble compound $\mathbf{2 e}$ was collected by filtration then was submitted to purification by recrystallization in $3 \mathrm{~mL}$ of absolute ethanol. The product $2 \mathbf{e}$ was obtained as white needles in $41 \%$ yield $(344 \mathrm{mg}) . \mathrm{Mp}=152$ $154{ }^{\circ} \mathrm{C} .{ }^{1} \mathrm{H}$ NMR (DMSO- $\left.d_{6}\right) \delta: 4.75$ (s, 2H, H-5', $\left.\underline{\mathrm{C}}_{2}\right)$; 
8.03 (m, 2H, H-3, Ar); 8.13 (m, 1H, H-4, Ar); 8.37 (m, 2H, H3, Ar); 11.31 (br s, $1 \mathrm{H}, \mathrm{NH}$ ). ${ }^{13} \mathrm{C}$ NMR (DMSO-d $\left.d_{6}\right) \delta: 32.95$ $\left(\mathrm{C}-5^{\prime}, \mathrm{CH}_{2} \mathrm{~S}\right) ; 127.23$ (C-2, Ar); 128.97 (C-3, Ar); 133.34 (C-4, Ar); 140.78 (C-1, Ar); 170.30 (C-4', C=O); 199.40 $\left(\mathrm{C}-2^{\prime}, \underline{\mathrm{C}}=\mathrm{S}\right.$ ). HRMS, $m / z: 310.9594$ found (calculated for $\mathrm{C}_{9} \mathrm{H}_{8} \mathrm{~N}_{2} \mathrm{O}_{3} \mathrm{NaS}_{3}[\mathrm{M}+\mathrm{Na}]^{+}$requires 310.9594$)$.

\section{N-(4-Oxo-2-thioxo-thiazolidin-3-yl)-benzamide (2f)}

In a $25 \mathrm{~mL}$ round-bottomed flask provided with a magnetic stirrer and condenser, a mixture of commercial 3-amino rhodanine $2 \mathbf{d}$ (500 mg, $3.37 \mathrm{mmol})$ and benzoyl chloride (0.39 $\mathrm{mL}, 3.37 \mathrm{mmol}$ ) was stirred in $5 \mathrm{~mL}$ of dry tetrahydrofuran at $60{ }^{\circ} \mathrm{C}$ during $2 \mathrm{~h}$. The solvent of the reaction mixture was eliminated in a rotary evaporator under reduced pressure and the yellowish crude residue crystallized after cooling down to room temperature. The crude solid was washed with toluene $(2 \times 5 \mathrm{~mL})$ and was collected by filtration. The desired product $2 \mathrm{f}$ was obtained as a yellowish powder in $90 \%$ yield $(767 \mathrm{mg}$ ) and was further used without purification. $\mathrm{Mp}=196-198^{\circ} \mathrm{C}$. ${ }^{1} \mathrm{H}$ NMR (DMSO- $d_{6}$ ) $\delta: 4.53$ (s, 2H, H-5', C $_{2}$ ); 7.56 (m, 2H, H-3, Ar); 7.66 (m, 1H, H-4, Ar); 7.93 (m, 2H, H-2, Ar); 11.56 (br s, $1 \mathrm{H}, \mathrm{NH}) .{ }^{13} \mathrm{C}$ NMR (DMSO- $\left.d_{6}\right) \delta: 33.43\left(\mathrm{C}-5^{\prime}\right.$, $\left.\mathrm{CH}_{2} \mathrm{~S}\right) ; 127.75$ (C-2, Ar); 128.72 (C-3, Ar); 130.90 (C-1, Ar); 132.76 (C-4, Ar); $164.44(\mathrm{NHC}=\mathrm{O}) ; 170.42\left(\mathrm{C}-4^{\prime}, \underline{\mathrm{C}}=\mathrm{O}\right)$; 200.14 (C-2', $\underline{\mathrm{C}}=\mathrm{S})$. HRMS, $m / z: 274.9927$ found (calculated for $\mathrm{C}_{10} \mathrm{H}_{8} \mathrm{~N}_{2} \mathrm{O}_{2} \mathrm{NaS}_{2}[\mathrm{M}+\mathrm{Na}]^{+}$requires 274.9925).

\section{4-Methoxy-N-(4-oxo-2-thioxo-thiazolidin-3-yl)-benzamide} (2g)

In a $25 \mathrm{~mL}$ round-bottomed flask provided with a magnetic stirrer and condenser, a mixture of commercial 3-amino rhodanine $2 \mathbf{d}$ (300 mg, $2.02 \mathrm{mmol}$ ) and $p$-methoxybenzoyl chloride ( $345 \mathrm{mg}, 2.02 \mathrm{mmol}$ ) was dispersed in $3 \mathrm{~mL}$ of dry toluene. The reaction mixture was heated at $50^{\circ} \mathrm{C}$ under vigorous magnetic stirring and the reaction was monitored by TLC on silica plates using dichloromethane/ethanol (9:1) as eluent ( $\left.2 \mathrm{~g} R_{f} 0.8\right)$. After $8 \mathrm{~h}$, the solvent of the reaction mixture was eliminated in a rotary evaporator under reduced pressure and the crude oil was dried under high vacuum $\left(10^{-2}\right.$ Torr $)$ at $25^{\circ} \mathrm{C}$ for $3 \mathrm{~h}$. The crude oil crystallized after standing at room temperature. The desired product $\mathbf{2 g}$ was obtained as yellowish powder in $98 \%$ yield (570 $\mathrm{mg}$ ) and was further used without purification. $\mathrm{Mp}=190$ $192{ }^{\circ} \mathrm{C} .{ }^{1} \mathrm{H}$ NMR (DMSO- $\left.d_{6}\right) \delta: 3.84\left(\mathrm{~s}, 3 \mathrm{H}, \mathrm{CH}_{3} \mathrm{O}\right) ; 4.51$ (s, 2H, H-5', $\mathrm{CH}_{2} \mathrm{~S}$ ); 7.08 (d, 2H, $J=8.9 \mathrm{~Hz}, \mathrm{H}-3, \mathrm{Ar}$ ); 7.92 (d, $2 \mathrm{H}, J=8.9 \mathrm{~Hz}, \mathrm{H}-2, \mathrm{Ar}) ; 11.39$ (br s, $1 \mathrm{H}, \mathrm{N} \underline{\mathrm{H}}) \cdot{ }^{13} \mathrm{C}$ NMR (DMSO-d $\left.d_{6}\right) \delta: 33.34\left(\mathrm{C}-5^{\prime}, \underline{\mathrm{CH}}_{2} \mathrm{~S}\right) ; 55.48\left(\underline{\mathrm{C}}_{3} \mathrm{O}\right)$; 113.95 (C-3, Ar); 122.96 (C-1, Ar); 129.79 (C-2, Ar); 162.67

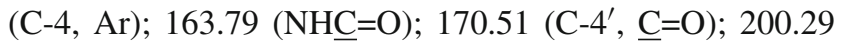
$\left(\mathrm{C}-2^{\prime}, \underline{\mathrm{C}}=\mathrm{S}\right.$ ). HRMS, $m / z: 305.0031$ found (calculated for $\mathrm{C}_{11} \mathrm{H}_{10} \mathrm{~N}_{2} \mathrm{O}_{3} \mathrm{NaS}_{2}[\mathrm{M}+\mathrm{Na}]^{+}$requires 305.0030).
N-(4-Oxo-2-thioxo-thiazolidin-3-yl)-2-phenyl-acetamide (2h)

In a $25 \mathrm{~mL}$ round-bottomed flask provided with a magnetic stirrer and condenser, a mixture of commercial 3-amino rhodanine $2 \mathbf{d}$ (300 mg, $2.02 \mathrm{mmol}$ ) and phenylacetyl chloride $(0.27 \mathrm{~mL}, 2.02 \mathrm{mmol})$ was dispersed in $3 \mathrm{~mL}$ of dry toluene. The reaction mixture was heated at $50{ }^{\circ} \mathrm{C}$ under vigorous magnetic stirring and the reaction was monitored by TLC on silica plates using dichloromethane/ethanol (9:1) as eluent

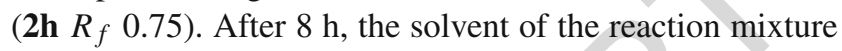
was eliminated in a rotary evaporator under reduced pressure and the crude product was dried under high vacuum $\left(10^{-2}\right.$ Torr) at $25{ }^{\circ} \mathrm{C}$ for $3 \mathrm{~h}$. The desired product $\mathbf{2 h}$ was obtained as yellowish powder in $98 \%$ yield $(538 \mathrm{mg})$ and was further used without purification. $\mathrm{Mp}=172-174{ }^{\circ} \mathrm{C}$. ${ }^{1} \mathrm{H}$ NMR (DMSO-d $) \delta: 3.66\left(\mathrm{~s}, 2 \mathrm{H}, \mathrm{CH}_{2}\right)$; 4.40-4.41 (br $\mathrm{s}, 2 \mathrm{H}, \mathrm{H}-5^{\prime}, \mathrm{CH}_{2} \mathrm{~S}$ ); $7.31-7.32$ (m, 5H, H-2, H-3, H-4, Ar); 11.41 (br s, $1 \overline{\mathrm{H}}, \mathrm{NH}) .{ }^{13} \mathrm{C} \mathrm{NMR}\left(\mathrm{DMSO}-d_{6}\right) \delta: 33.38(\mathrm{C}-$ 5', $\left.\mathrm{CH}_{2} \mathrm{~S}\right) ; 126.52$ (C-4, Ar); 128.19 (C-3, Ar); 129.11 (C-2, Ar); 134.65 (C-1, Ar); 168.39 (NHC $=0) ; 170.18\left(\mathrm{C}-4^{\prime} \underline{\mathrm{C}}=\mathrm{O}\right)$; $199.99\left(\mathrm{C}-2^{\prime}, \mathrm{C}=\mathrm{S}\right)$. HRMS, $m / z: 289.0082$ found (calculated for $\mathrm{C}_{11} \mathrm{H}_{10} \mathrm{~N}_{2} \mathrm{O}_{2} \mathrm{NaS}_{2}[\mathrm{M}+\mathrm{Na}]^{+}$requires 289.0081).

N-(4-Oxo-2-thioxo-thiazolidin-3-yl)-3-phenylpropionamide $(2 \mathrm{i})$

In a $25 \mathrm{~mL}$ round-bottomed flask provided with a magnetic stirrer and condenser, a mixture of commercial 3-amino rhodanine $2 \mathbf{d}$ ( $50 \mathrm{mg}, 0.34 \mathrm{mmol}$ ) and 2-phenylpropionyl chloride $(50 \mu \mathrm{L}, 0.34 \mathrm{mmol})$ was dispersed in $1 \mathrm{~mL}$ of dry toluene. The reaction mixture was heated at $50{ }^{\circ} \mathrm{C}$ under vigorous magnetic stirring and the reaction was monitored by TLC on silica plates using dichloromethane/ethanol (9:1) as eluent ( $2 \mathbf{i} R_{f} 0.75$ ). After $23 \mathrm{~h}$, the solvent of the reaction mixture was eliminated in a rotary evaporator under reduced pressure. The crude residue was dissolved in dichloromethane $(15 \mathrm{~mL})$ then, this organic layer was washed with $4 \mathrm{~mL}$ of saturated hydrogen carbonate $\mathrm{NaHCO}_{3}$ and was dried over $\mathrm{MgSO}_{4}$. After filtration, the solvent of the filtrate was eliminated in vacuo and the crude residue was dried under high vacuum $\left(10^{-2}\right.$ Torr) at $25^{\circ} \mathrm{C}$ for $1 \mathrm{~h}$. The desired product $\mathbf{2 i}$ was obtained as orange powder in $84 \%$ yield $(80 \mathrm{mg}$ ) and was further used without purification. $\mathrm{Mp}=190-192{ }^{\circ} \mathrm{C}$ . ${ }^{1} \mathrm{H}$ NMR (DMSO- $\left.d_{6}\right) \delta: 2.67(\mathrm{dd}, 2 \mathrm{H}, J=6.3,8.3 \mathrm{~Hz}$, $2 \mathrm{H}, \mathrm{CH}_{2} \mathrm{Ar}$ ); 2.95 (m, $\left.2 \mathrm{H}, \mathrm{CH}_{2} \mathrm{CO}\right) ; 4.47-4.48$ (br s, $1 \mathrm{H}$, H-5', $\underline{\mathrm{CH}}_{2} \mathrm{~S}$ ); 7.32-7.35 (m, 5H, H-2, H-3, H-4, Ar); 11.05 (br s, $1 \mathrm{H}, \mathrm{N} \underline{\mathrm{H}}) .{ }^{13} \mathrm{C} \mathrm{NMR}$ (DMSO-d 6 ) $\delta: 30.41\left(\underline{\mathrm{CH}}_{2} \mathrm{Ar}\right)$; $33.32\left(\mathrm{CH}_{2} \mathrm{CO}\right) ; 34.49\left(\mathrm{C}-5^{\prime}, \mathrm{CH}_{2} \mathrm{~S}\right) ; 126.02-128.27$ (C-2, C-3, C-4, Ar); 140.53 (C-1, Ar); 169.79 (NHC=O); 170.24 (C-4', $\underline{\mathrm{C}}=\mathrm{O}) ; 200.03$ (C-2', $\mathrm{C}=\mathrm{S}) . \mathrm{HRMS}, m / z: 303.0239$ found (calculated for $\mathrm{C}_{12} \mathrm{H}_{12} \mathrm{~N}_{2} \mathrm{O}_{2} \mathrm{NaS}_{2}[\mathrm{M}+\mathrm{Na}]^{+}$requires 303.0238). 
Standard procedure for the preparation of 4,5-dihalogeno1H-pyrrol-2-carboxylic acid [3-(4-oxo-2-thioxothiazolidin-5-ylidene) -propyl]-amide $\mathbf{3}(\boldsymbol{a}, \boldsymbol{b})$

In a $10 \mathrm{~mL}$ glass tube were placed successively 4,5dihalogeno-1 $H$-pyrrole-2-carboxylic acid (3-oxo-propyl)amide $\mathbf{1}(\mathbf{a}, \mathbf{b})$ (3.09 $\mathrm{mmol})$, commercial rhodanine $\mathbf{2 a}$ (3.09 mmol, 1 equiv.), piperidine ( $0.31 \mathrm{mmol}, 0.1$ equiv.) and glacial acetic acid $(0.31 \mathrm{mmol}, 0.1$ equiv. $)$ in $12 \mathrm{~mL}$ of absolute ethanol. The glass tube was sealed with a snap cap and placed in the Explorer®24 CEM microwave cavity ( $P$ $=300 \mathrm{~W}$ ). The mixture was irradiated at $150{ }^{\circ} \mathrm{C}$ (with a power of $200 \mathrm{~W}$ ) for $20 \mathrm{~min}$ under vigorous magnetic stirring. After microwave dielectric heating, the crude reaction mixture was allowed to cool down at room temperature and the volatile compounds of the reaction mixture were eliminated in a rotary evaporator under reduced pressure. The crude residue was submitted to purification by preparative chromatography (Combi Flash $R_{f} 200$ psi apparatus, detector UV $254 \mathrm{~nm}$ ) on pre-packed column of silica gel $60 \mathrm{~F}$ 254 Merck using dichloromethane/ethanol (9:1) as eluent. Pooling and evaporation of the solvents in vacuo gave the expected compounds $\mathbf{3}(\mathbf{a}, \mathbf{b})$ which, were dried under high vacuum $\left(10^{-2}\right.$ Torr $)$ at $25^{\circ} \mathrm{C}$ for $1 \mathrm{~h}$.

\section{4,5-Dibromo-1H-pyrrol-2-carboxylic acid [3-(4-oxo-2- thioxo-thiazolidin-5-ylidene)-propyl]-amide (3a)}

Orange powder. $R_{f}=0.83$. Yield $=88 \% . \mathrm{Mp}=156{ }^{\circ} \mathrm{C}$ (decomposition). ${ }^{1} \mathrm{H}$ NMR (DMSO-d 6$) \delta: 2.41(\mathrm{~m}, 2 \mathrm{H}$, $\left.\mathrm{CH}_{2} \mathrm{CH}=\right) ; 3.41\left(\mathrm{~m}, 2 \mathrm{H}, \mathrm{NHCH}_{2}\right) ; 6.81(\mathrm{t}, 1 \mathrm{H}, J=7.6 \mathrm{~Hz}$, $=\mathrm{CH}) ; 6.87(\mathrm{~d}, 1 \mathrm{H}, J=2.3 \mathrm{~Hz}, \mathrm{H}-3,=\mathrm{CH}, \mathrm{Ar}) ; 8.31(\mathrm{t}, 1 \mathrm{H}$, $J=6.0 \mathrm{~Hz}, \mathrm{~N} \underline{\mathrm{HCO}}$ ); 12.71 (br s, $1 \mathrm{H}, \mathrm{H}-1, \underline{\mathrm{H}}, \mathrm{Ar}) ; 13.60$ (br $\left.\mathrm{s}, 1 \mathrm{H}, \mathrm{H}-3^{\prime}, \mathrm{N} \underline{\mathrm{H}}\right) .{ }^{13} \mathrm{C} \mathrm{NMR}\left(\mathrm{DMSO}-d_{6}\right) \delta: 32.27\left(\mathrm{CH}_{2} \mathrm{CH}=\right)$; $36.79\left(\mathrm{NHCH}_{2}\right) ; 97.79(\mathrm{C}-4,=\underline{\mathrm{CBr}}, \mathrm{Ar}) ; 104.69\left(\mathrm{C}-4^{\prime}, \underline{\mathrm{C}}=\mathrm{O}\right)$; 112.59 (C-3, =대, Ar); $124.74\left(\mathrm{C}-5^{\prime}, \underline{\mathrm{C}}=\mathrm{CH}\right) ; 127.88$ (C-5, $=\underline{\mathrm{CBr}}, \mathrm{Ar}) ; 130.36(\mathrm{C}-2, \mathrm{Ar}) ; 135.02(=\underline{\mathrm{CH}}) ; 159.00(\mathrm{NH}-$ $\underline{\mathrm{C}}=\mathrm{O}) ; 167.49$ (C-4', $\underline{\mathrm{C}}=\mathrm{O}) ; 195.95\left(\mathrm{C}-2^{\prime}, \underline{\mathrm{C}}=\mathrm{S}\right)$. HRMS, $m / z$ : 459.8403 found (calculated for $\mathrm{C}_{11} \mathrm{H}_{9} \mathrm{~N}_{3} \mathrm{O}_{2}^{79} \mathrm{Br}_{2} \mathrm{NaS}_{2}$ $[\mathrm{M}+\mathrm{Na}]^{+}$requires 459.8401$)$.

4,5-Dichloro-1H-pyrrol-2-carboxylic acid [3-(4-oxo-2thioxo-thiazolidin-5-ylidene)-propyl]-amide (3b)

Orange powder. $R_{f}=0.79$. Yield $=82 \% . \mathrm{Mp}=180{ }^{\circ} \mathrm{C}$ (decomposition). ${ }^{1} \mathrm{H}$ NMR (DMSO-d 6 ) $\delta: 2.40$ (q, $2 \mathrm{H}, J=$ $\left.6.5 \mathrm{~Hz}, \mathrm{CH}_{2} \mathrm{CH}=\right) ; 3.43$ (q, $\left.2 \mathrm{H}, J=6.5 \mathrm{~Hz}, \mathrm{NHCH}_{2}\right) ; 6.82$ $(\mathrm{m}, 1 \mathrm{H},=\mathrm{CH}) ; 6.84$ (s, 1H, H-3, =C $\underline{\mathrm{H}}, \mathrm{Ar}) ; 8.34$ (t, 1H, $J=$ $5.8 \mathrm{~Hz}, \mathrm{NHCO}$ ); 12.74 (br s, $1 \mathrm{H}, \mathrm{NH}, \mathrm{Ar}$ ); 13.58 (br s, $1 \mathrm{H}, \mathrm{H}-$ $\left.3^{\prime}, \mathrm{NH}\right) .{ }^{13} \mathrm{C}$ NMR (DMSO-d 6$) \delta: 32.26\left(\mathrm{CH}_{2} \mathrm{CH}=\right) ; 36.80$ $\left(\mathrm{NHCH}_{2}\right) ; 107.92(\mathrm{C}-4,=\mathrm{CCl}, \mathrm{Ar}) ; 109.65(\mathrm{C}-3,=\mathrm{CH}, \mathrm{Ar})$; $114.94\left(\mathrm{C}-4^{\prime}, \underline{\mathrm{C}}=\mathrm{O}\right) ; 124.61$ (C-5, =Cl, Ar); $124.74(\mathrm{C}-$ 5', $\underline{\mathrm{C}}=\mathrm{CH} ; 130.38$ (C-2, Ar); $134.96(=\underline{\mathrm{CH}}) ; 159.12(\mathrm{NH}-$
$\underline{\mathrm{C}}=\mathrm{O}) ; 167.48\left(\mathrm{C}-4^{\prime}, \underline{\mathrm{C}}=\mathrm{O}\right) ; 195.94\left(\mathrm{C}-2^{\prime}, \underline{\mathrm{C}}=\mathrm{S}\right)$. HRMS, $m / z: 371.9411$ found (calculated for $\mathrm{C}_{11} \mathrm{H}_{9} \mathrm{~N}_{3} \mathrm{O}_{2}^{35} \mathrm{Cl}_{2} \mathrm{NaS}_{2}$ $[\mathrm{M}+\mathrm{Na}]^{+}$requires 371.9411$)$.

\section{(5-\{3-[(4,5-Dibromo-1H-pyrrol-2-carbonyl)-amino]-} propylidene\} -4-oxo-2-thioxo-thiazolidin-3-yl)-acetic acid (3c)

In a $10 \mathrm{~mL}$ glass tube were placed successively 4,5-dibromo$1 H$-pyrrole-2-carboxylic acid (3-oxo-propyl)-amide $\mathbf{1 a}$ (200 $\mathrm{mg}, 0.62 \mathrm{mmol}$ ), commercial 2-(4-oxo-2-thioxo-thiazolidin3 -yl)-acetic acid $2 \mathbf{b}$ (118 mg, $0.62 \mathrm{mmol}, 1$ equiv.), piperidine ( $6 \mu \mathrm{L}, 0.062 \mathrm{mmol}, 0.1$ equiv.), glacial acetic acid (4 $\mu \mathrm{L}, 0.062 \mathrm{mmol}, 0.1$ equiv.) in $2.5 \mathrm{~mL}$ of absolute ethanol. The glass tube was sealed with a snap cap and placed in the Monowave ${ }^{\circ} 200$ Anton-Paar microwave cavity $(P=800 \mathrm{~W})$. The mixture was irradiated at $110^{\circ} \mathrm{C}$ for $40 \mathrm{~min}$ under vigorous magnetic stirring. After microwave dielectric heating, the crude reaction mixture was allowed to cool down at room temperature and the volatile compounds of the reaction mixture were eliminated in a rotary evaporator under reduced pressure. The crude residue was submitted to purification by preparative chromatography (Combi Flash $R_{f} 200$ psi apparatus, detector UV $254 \mathrm{~nm}$ ) on pre-packed column of silica gel 60F 254 Merck using dichloromethane/methanol (9:1) as eluent (3c: $R_{f}$ 0.10). Pooling and evaporation of the solvents in vacuo gave the desired compound $\mathbf{3 c}$ which, was dried under high vacuum $\left(10^{-2}\right.$ Torr $)$ at $25^{\circ} \mathrm{C}$ for $1 \mathrm{~h}$. 3c was obtained as yellow powder in $46 \%$ yield $(140 \mathrm{mg})$. $\mathrm{Mp}=210-212{ }^{\circ} \mathrm{C} .{ }^{1} \mathrm{H}$ NMR (DMSO- $\left.d_{6}\right) \delta: 2.50(\mathrm{~m}, 2 \mathrm{H}$, $\left.\mathrm{CH}_{2} \mathrm{CH}=\right) ; 3.42\left(\mathrm{~m}, 2 \mathrm{H}, \mathrm{NHCH}_{2}\right) ; 4.63$ (s, 2H, $\left.\underline{\mathrm{CH}}_{2} \mathrm{CO}\right)$; 6.87 (s, 1H, =C- $\underline{\mathrm{H}}, \mathrm{Ar}) ; 7.07$ (t, $1 \mathrm{H}, J=7.5 \mathrm{~Hz},=\mathrm{C} \underline{\mathrm{H}}) ; 8.35$ $(\mathrm{t}, 1 \mathrm{H}, J=5.5 \mathrm{~Hz}, \mathrm{NHCO}) ; 12.71$ (br s, $1 \mathrm{H}, \mathrm{NH}) .{ }^{13} \mathrm{C} \mathrm{NMR}$ $\left(\mathrm{DMSO}-d_{6}\right) \delta: 30.64\left(\underline{\mathrm{CH}}_{2} \mathrm{CH}=\right) ; 36.79\left(\mathrm{NHCH}_{2}\right) ; 44.81$ $\left(\underline{\mathrm{CH}}_{2} \mathrm{CO}\right) ; 97.77$ (C-4, = $\left.\underline{\mathrm{CBr}}, \mathrm{Ar}\right) ; 104.48\left(\mathrm{C}-5^{\prime}, \underline{\mathrm{C}}=\mathrm{CH}\right)$; 112.49 (C-3, =대, Ar); 126.72 (C-5, =C $B r, A r) ; 127.88$ (C2, Ar); $137.84(\mathrm{C}=\underline{\mathrm{CH}}) ; 159.05(\mathrm{NH}-\underline{\mathrm{C}}=\mathrm{O}) ; 164.55\left(\mathrm{C}-4^{\prime}\right.$, $\underline{\mathrm{C}}=\mathrm{O}) ; 167.10\left(\mathrm{C}=\mathrm{O}, \underline{\mathrm{CO}}_{2} \mathrm{H}\right) ; 193.66\left(\mathrm{C}-2^{\prime}, \underline{\mathrm{C}}=\mathrm{S}\right) . \mathrm{HRMS}$, $m / z: 517.8448$ found (calculated for $\mathrm{C}_{13} \mathrm{H}_{11} \mathrm{~N}_{3} \mathrm{O}_{4}^{79} \mathrm{Br}_{2} \mathrm{NaS}_{2}$ $[\mathrm{M}+\mathrm{Na}]^{+}$requires 517.8455$)$.

(5-\{3-[(4,5-Dibromo-1H-pyrrol-2-carbonyl)-amino]propylidene\} -4-oxo-2-thioxo-thiazolidin-3-yl)-propionic $\operatorname{acid}(3 d)$

In a $10 \mathrm{~mL}$ glass tube were placed successively 4,5-dibromo$1 H$-pyrrole-2-carboxylic acid (3-oxo-propyl)-amide $1 a$ (79 $\mathrm{mg}, \quad 0.24 \mathrm{mmol}), \quad 3$-(4-oxo-2-thioxo-thiazolidin-3-yl)propionic acid 2c (50 mg, $0.24 \mathrm{mmol}, 1$ equiv.), commercial sodium acetate AcONa (20 mg, $0.24 \mathrm{mmol}, 1$ equiv.), and glacial acetic acid ( $90 \mu \mathrm{L}, 1.6 \mathrm{mmol}, 6.58$ equiv.). The glass tube was sealed with a snap cap and placed in the Explorer®24 CEM microwave cavity $(P=300 \mathrm{~W})$. The mixture 
was irradiated at $140{ }^{\circ} \mathrm{C}$ (with a power of $60 \mathrm{~W}$ ) for $20 \mathrm{~min}$ under vigorous magnetic stirring. After microwave dielectric heating, the crude reaction mixture was allowed to cool down at room temperature and to the oily crude reaction mixture was added $1 \mathrm{~mL}$ of deionized water. After triturating, the insoluble product $\mathbf{3 d}$ was collected by filtration and was submitted to purification by preparative chromatography (Combi Flash $R_{f} 200$ psi apparatus, detector UV $254 \mathrm{~nm}$ ) on pre-packed column of silica gel 60F 254 Merck using dichloromethane/ethanol (9:1) as eluent (3d $R_{f}$ 0.49). Pooling and evaporation of the solvents in vacuo gave the desired compound 3d which, was dried under high vacuum $\left(10^{-2}\right.$ Torr) at $25^{\circ} \mathrm{C}$ for $1 \mathrm{~h}$. 3d was obtained as yellowish needles in $46 \%$ yield $(58 \mathrm{mg})$. $\mathrm{Mp}=90{ }^{\circ} \mathrm{C}$ (decomposition). ${ }^{1} \mathrm{H}$ NMR (DMSO- $\left.d_{6}\right) \delta: 2.45\left(\mathrm{~m}, 2 \mathrm{H}, \mathrm{CH}_{2} \mathrm{CH}=\right) ; 2.56(\mathrm{~m}$, $\left.2 \mathrm{H}, \mathrm{CH}_{2} \mathrm{CO}\right) ; 3.41\left(\mathrm{~m}, 2 \mathrm{H}, \mathrm{NHCH}_{2}\right) ; 4.15$ (t, $2 \mathrm{H}, J=7.8$ $\left.\mathrm{Hz}, 2 \mathrm{H}, \mathrm{NC}_{2}\right) ; 6.89$ (s, 1H, H-3, =C- $\left.\underline{\mathrm{H}}, \mathrm{Ar}\right) ; 7.01$ (t, $1 \mathrm{H}$, $J=7.5 \mathrm{~Hz}, \mathrm{C}=\mathrm{CH}) ; 8.32(\mathrm{t}, 1 \mathrm{H}, J=5.5 \mathrm{~Hz}, 1 \mathrm{H}, \mathrm{NHCO})$; 12.72 (br s, $1 \mathrm{H}, \mathrm{H}-1, \mathrm{~N} \underline{\mathrm{H}}, \mathrm{Ar}$ ). ${ }^{13} \mathrm{C}$ NMR (DMSO-d 6 ) $\delta$ : $30.70\left(\underline{\mathrm{CH}}_{2} \mathrm{CH}=\right) ; 32.23\left(\underline{\mathrm{CH}}_{2} \mathrm{CO}\right) ; 36.82\left(\mathrm{NCH}_{2}\right) ; 97.80$ $(\mathrm{C}-4,=\underline{\mathrm{CBr}}, \mathrm{Ar}) ; 104.72(\mathrm{C}-5,=\underline{\mathrm{CBr}}, \mathrm{Ar}) ; 112.60(\mathrm{C}-3,=\underline{\mathrm{CH}}$, $\mathrm{Ar}) ; 127.17\left(\mathrm{C}-5^{\prime}, \underline{\mathrm{C}}=\mathrm{CH}\right) ; 127.87(\mathrm{C}-2, \mathrm{Ar}) ; 136.61(\underline{\mathrm{CH}}=)$; $159.04(\mathrm{NH}-\underline{\mathrm{C}}=\mathrm{O}) ; 164.86\left(\mathrm{C}-4^{\prime}, \mathrm{C}=\mathrm{O}\right) ; 171.67\left(\underline{\mathrm{CO}}_{2} \mathrm{H}\right)$; $193.65\left(\mathrm{C}-2^{\prime}, \underline{\mathrm{C}}=\mathrm{S}\right)$. HRMS, $m / z: 507.8636$ found (calculated for $\mathrm{C}_{14} \mathrm{H}_{12} \mathrm{~N}_{3} \mathrm{O}_{4}^{79} \mathrm{Br}_{2} \mathrm{~S}_{2}[\mathrm{M}-\mathrm{H}]^{-}$requires 507.8636).

\section{4,5-Dibromo-1H-pyrrol-2-carboxylic acid [3-(3-amino-4- oxo- 2-thioxo-thiazolidin-5-ylidene)-propyl]-amide (3e)}

In a $10 \mathrm{~mL}$ glass tube were placed successively 4,5-dibromo$1 H$-pyrrole-2-carboxylic acid (3-oxo-propyl)-amide $\mathbf{1 a}$ (100 $\mathrm{mg}, 0.31 \mathrm{mmol}$ ), commercial 3-amino rhodanine 2d (46 $\mathrm{mg}, 0.31 \mathrm{mmol}, 1$ equiv.), dry triethylamine $\mathrm{Et}_{3} \mathrm{~N}(4 \mu \mathrm{L}$, $0.031 \mathrm{mmol}, 0.1$ equiv.), glacial acetic acid $\mathrm{AcOH}(2 \mu \mathrm{L}$, $0.031 \mathrm{mmol}, 0.1$ equiv.) in $1 \mathrm{~mL}$ of ethyl acetate AcOEt. The glass tube was placed (open vessel) in the Explorer®24 CEM microwave cavity $(P=300 \mathrm{~W})$ and the mixture was irradiated at $70{ }^{\circ} \mathrm{C}$ (with a power of $50 \mathrm{~W}$ ) for $30 \mathrm{~min}$ under vigorous magnetic stirring. After microwave dielectric heating, the crude reaction mixture was allowed to cool down at room temperature and to the crude reaction mixture was added $5 \mathrm{~mL}$ of cyclohexane. This heterogeneous mixture in the tube was submitted to ultrasound in a Branson 1510 apparatus at $25{ }^{\circ} \mathrm{C}$ during $30 \mathrm{~min}$. The yellowish desired compound $\mathbf{3 e}$ was collected by filtration, washed with $\mathrm{Et}_{2} \mathrm{O}(2 \times 5 \mathrm{~mL})$ and was purified by preparative chromatography (Combi Flash $R_{f} 200$ psi apparatus, detector UV $254 \mathrm{~nm}$ ) on pre-packed column of silica gel 60F 254 Merck using dichloromethane/methanol (9:1) as eluent (3e $R_{f}$ 0.69). Pooling and evaporation of the solvents in vacuo gave the desired compound $\mathbf{3 e}$ which, was dried under high vacuum $\left(10^{-2}\right.$ Torr $)$ at $25{ }^{\circ} \mathrm{C}$ for $1 \mathrm{~h}$. 3e was obtained as a yellowish powder in $71 \%$ yield $(100 \mathrm{mg}) .{ }^{1} \mathrm{H}$ NMR
(DMSO- $\left.d_{6}\right) \delta: 2.45\left(\mathrm{~m}, 2 \mathrm{H}, \mathrm{C}_{2} \mathrm{CH}=\right) ; 3.41\left(\mathrm{~m}, 2 \mathrm{H}, \mathrm{NC}_{2}\right)$; $5.99(\mathrm{~m}, 1 \mathrm{H}, \mathrm{C}=\mathrm{CH}) ; 6.95(\mathrm{~s}, 1 \mathrm{H}, \mathrm{H}-3, \mathrm{Ar}) ; 8.28(\mathrm{~m}, 1 \mathrm{H}$, NH-CO); 12.79 (br s, 1H, NH, Ar). HRMS, $m / z: 452.8693$ found (calculated for $\mathrm{C}_{11} \mathrm{H}_{11} \mathrm{~N}_{4} \mathrm{O}_{2}^{79} \mathrm{Br}_{2} \mathrm{~S}_{2}[\mathrm{M}+\mathrm{H}]^{+}$requires 452.8690).

4,5-Dibromo-1H-pyrrol-2-carboxylic acid [3-(3-benzenesulfonylamino-4-oxo-2-thioxo-thiazolidin-5-ylidene)propyl]-amide (3f)

In a $10 \mathrm{~mL}$ glass tube were placed successively 4,5-dibromo$1 H$-pyrrole-2-carboxylic acid (3-oxo-propyl)-amide 1a (100 $\mathrm{mg}, \quad 0.31 \mathrm{mmol}), \quad \mathrm{N}$-(4-oxo-2-thioxo-thiazolidin-3-yl)benzenesulfonamide $2 \mathbf{e}(89 \mathrm{mg}, 0.31 \mathrm{mmol}, 1$ equiv.), piperidine ( $3 \mu \mathrm{L}, 0.031 \mathrm{mmol}, 0.1$ equiv.), glacial acetic acid (2 $\mu \mathrm{L}, 0.031 \mathrm{mmol}, 0.1$ equiv.) in $1.2 \mathrm{~mL}$ of absolute ethanol. The glass tube was sealed with a snap cap and placed in the Monowave ${ }^{\circledR} 200$ Anton-Paar microwave cavity $(P=800 \mathrm{~W})$. The mixture was irradiated at $150{ }^{\circ} \mathrm{C}$ for 20 min under vigorous magnetic stirring. After microwave dielectric heating, the crude reaction mixture was allowed to cool down at room temperature and the volatile compounds of the reaction mixture were eliminated in a rotary evaporator under reduced pressure. To the black crude residue was added $\mathrm{Et}_{2} 0(5 \mathrm{~mL})$ and after triturating, the insoluble compound $\mathbf{3 f}$ was collected by filtration. Then, $\mathbf{3 f}$ was submitted to purification by preparative chromatography (Combi Flash $R_{f} 200$ psi apparatus, detector UV $254 \mathrm{~nm}$ ) on pre-packed column of silica gel 60F 254 Merck using dichloromethane/methanol (9:1) as eluent ( $3 \mathbf{f} R_{f}$ 0.69). Pooling and evaporation of the solvents in vacuo gave the desired compound $\mathbf{3 f}$ which, was dried under high vacuum $\left(10^{-2}\right.$ Torr $)$ at $25^{\circ} \mathrm{C}$ for $1 \mathrm{~h}$. $3 \mathbf{f}$ was obtained as an orange powder in $19 \%$ yield $(35 \mathrm{mg}) . \mathrm{Mp}=2424-226^{\circ} \mathrm{C}$. ${ }^{1} \mathrm{H}$ NMR (DMSO- $\left.d_{6}\right) \delta: 2.45\left(\mathrm{~m}, 2 \mathrm{H}, \mathrm{C}_{2} \mathrm{CH}=\right) ; 3.42(\mathrm{~m}$, $\left.2 \mathrm{H}, \mathrm{NC}_{2}\right) ; 6.87(\mathrm{~d}, 1 \mathrm{H}, J=2.7 \mathrm{~Hz},=\mathrm{C} \underline{\mathrm{H}}, \mathrm{Ar}) ; 7.07(\mathrm{t}$, $1 \mathrm{H}, J=7.6 \mathrm{~Hz},=\mathrm{C} \underline{\mathrm{H}}) ; 7.56\left(\mathrm{~m}, 2 \mathrm{H}, \mathrm{H}-3^{\prime \prime}, \mathrm{Ar}\right) ; 7.67(\mathrm{~m}$, $\left.1 \mathrm{H}, \mathrm{H}-4^{\prime \prime}, \mathrm{Ar}\right) ; 7.80$ (m, 2H, H-2", Ar); 8.34 (t, 1H, J = $5.9 \mathrm{~Hz}, \mathrm{NHCO}$ ); 11.51 (br s, $1 \mathrm{H}, \mathrm{NHSO}_{2}$ ); 12.71 (br s, $1 \mathrm{H}$, NHPyr). ${ }^{13} \mathrm{C}$ NMR (DMSO- $\left.d_{6}\right) \delta: 31.77\left(\underline{\mathrm{CH}}_{2} \mathrm{CH}=\right) ; 36.66$ $\left(\mathrm{NCH}_{2}\right) ; 97.79(\mathrm{C}-4,=\underline{\mathrm{CBr}}, \mathrm{Ar}) ; 104.74(\mathrm{C}-5,=\underline{\mathrm{CBr}}, \mathrm{Ar})$; 11260 (C-3, = $\underline{\mathrm{CH}}, \mathrm{Ar}) ; 123.41\left(\mathrm{C}-5^{\prime}, \underline{\mathrm{C}}=\mathrm{CH}\right) ; 127.22\left(\mathrm{C}-2^{\prime \prime}\right.$, $\mathrm{Ar}) ; 127.87$ (C-2, =-ㅡ-H, Ar); 129.07 (C-3", Ar); 133.48 (C4", Ar); $138.92(\mathrm{C}=\underline{\mathrm{CH}}) ; 140.59\left(\mathrm{C}-1^{\prime \prime}, \mathrm{Ar}\right) ; 159.05(\mathrm{NH}-$ $\underline{\mathrm{C}}=\mathrm{O}) ; 161.73\left(\mathrm{C}-4^{\prime}, \underline{\mathrm{C}}=\mathrm{O}\right) ; 190.37\left(\mathrm{C}-2^{\prime}, \underline{\mathrm{C}}=\mathrm{S}\right)$. HRMS, $m / z: 614.8438$ found (calculated for $\mathrm{C}_{17} \mathrm{H}_{14} \mathrm{~N}_{4} \mathrm{O}_{4}^{79} \mathrm{Br}_{2} \mathrm{NaS}_{2}$ $[\mathrm{M}+\mathrm{Na}]^{+}$requires 614.8442).

Standard procedure for the preparation of 4,5-dibromo- $1 \mathrm{H}$ pyrrol-2-carboxylic acid [3-(3-substituted amino-4-oxo-2thioxo-thiazolidin-5-ylidene)-propyl]-amide $(\mathbf{3 g})$ and $\mathbf{3}(\boldsymbol{i}, \boldsymbol{j})$.

In a $10 \mathrm{~mL}$ glass tube were placed successively 4,5-dibromo$1 H$-pyrrole-2-carboxylic acid (3-oxo-propyl)-amide 1a (52- 
$122 \mathrm{mg}, 0.16-0.38 \mathrm{mmol}), N$-acyl rhodanine $\mathbf{2}(\mathbf{f}-\mathbf{i})(45-100$ $\mathrm{mg}, 0.16-0.38 \mathrm{mmol}, 1$ equiv.), commercial sodium acetate AcONa (14-31 mg, 0.16-0.38 mmol, 1 equiv.), and glacial acetic acid (61-140 $\mu \mathrm{L}, 1.06-2.47 \mathrm{mmol}, 6.58$ equiv.). The glass tube was sealed with a snap-cap and placed in the Explorer®24 CEM microwave cavity $(P=300 \mathrm{~W})$. The mixture was irradiated at $120^{\circ} \mathrm{C}$ (with a power of $100 \mathrm{~W}$ ) for 20 min under vigorous magnetic stirring. After microwave dielectric heating, the crude reaction mixture was allowed to cool down at room temperature and deionized water $(2$ $\mathrm{mL}$ ) was added to the brown crude reaction mixture. The resulting suspension was submitted to ultrasound in a Branson 1510 apparatus at $25{ }^{\circ} \mathrm{C}$ during $30 \mathrm{~min}$ and the beige insoluble product 3 was collected by filtration. Then, compound $\mathbf{3}$ was triturated in $5 \mathrm{~mL}$ of $\mathrm{Et}_{2} \mathrm{O}$ for compounds $\mathbf{3 g}$ and $\mathbf{3}(\mathbf{i}, \mathbf{j})$ or in $5 \mathrm{~mL}$ of dichloromethane for compound $3 \mathbf{h}^{*}$ and again was collected by filtration. The crude products $\mathbf{3 g}$ and $\mathbf{3}(\mathbf{i}, \mathbf{j})$ were purified by preparative chromatography (Combi Flash $R_{f} 200$ psi apparatus, detector UV 254 $\mathrm{nm}$ ) on pre-packed column of silica gel 60F 254 Merck using dichloromethane/methanol (9:1) as eluent. Pooling and evaporation of the solvents it in vacuo gave the expected compound $\mathbf{3 g}$ and $\mathbf{3}(\mathbf{i}, \mathbf{j})$ and were dried under high vacuum $\left(10^{-2}\right.$ Torr) at $25{ }^{\circ} \mathrm{C}$ during $1 \mathrm{~h} .\left(^{*}\right)$ The compound 3h was purified by recrystallization in dichloromethane $\mathrm{CH}_{2} \mathrm{Cl}_{2}$.

4,5-Dibromo-1H-pyrrol-2-carboxylic acid [3-(3-benzoylamino-4-oxo-2-thioxo-thiazolidin-5-ylidene)-propyl]amide $(3 g)$

Compound $\mathbf{3 g}\left(R_{f} 0.69\right)$ was prepared in $52 \%$ yield (90 $\mathrm{mg}$ ) from 4,5-dibromo- $1 \mathrm{H}$-pyrrole-2-carboxylic acid (3oxo-propyl)-amide $1 \mathrm{a}(100 \mathrm{mg}, 0.31 \mathrm{mmol}), \mathrm{N}$-(4-oxo-2thioxo-thiazolidin-3-yl)-benzamide $\mathbf{2 f}$ (78 $\mathrm{mg}, 0.31 \mathrm{mmol}$ ), sodium acetate AcONa $(25 \mathrm{mg}, 0.31 \mathrm{mmol})$ in glacial acetic acid (120 $\mu \mathrm{L}, 2 \mathrm{mmol}, 6.58$ equiv.) according to the standard procedure. $\mathrm{Mp}=242-244{ }^{\circ} \mathrm{C} .{ }^{1} \mathrm{H}$ NMR (DMSO- $\left.d_{6}\right) \delta$ : $2.50\left(\mathrm{~m}, 2 \mathrm{H}, \underline{\mathrm{C}}_{2} \mathrm{CH}=\right) ; 3.33\left(\mathrm{~m}, 2 \mathrm{H}, \mathrm{NC}_{2}\right) ; 6.89(\mathrm{~d}, 1 \mathrm{H}$, $J=2.7 \mathrm{~Hz},=\mathrm{CH}, \mathrm{Ar}) ; 7.20(\mathrm{t}, 1 \mathrm{H}, J=7.6 \mathrm{~Hz},=\mathrm{C} \underline{\mathrm{H}})$; 7.57 (m, 2H, H-3", Ar); 7.67 (m, 1H, H-4", Ar); 7.94 (m, $\left.2 \mathrm{H}, \mathrm{H}-2^{\prime \prime}, \mathrm{Ar}\right) ; 8.39$ (t, $\left.1 \mathrm{H}, J=6.1 \mathrm{~Hz}, \mathrm{~N} \underline{\mathrm{HCO}}\right) ; 11.72$

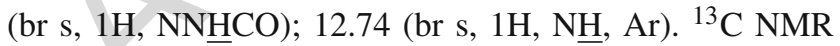
(DMSO- $\left.d_{6}\right) \delta: 31.98\left(\mathrm{CH}_{2} \mathrm{CH}=\right) ; 36.75\left(\mathrm{NCH}_{2}\right) ; 97.80(\mathrm{C}-$ $4,=\mathrm{CBr}, \mathrm{Ar}) ; 104.76(\mathrm{C}-5,=\underline{\mathrm{CBr}}, \mathrm{Ar}) ; 112.61(\mathrm{C}-3,=\underline{\mathrm{CH}}$, $\mathrm{Ar}) ; 123.84\left(\mathrm{C}-5^{\prime},=\mathrm{C}\right) ; 127.73\left(\mathrm{C}-2^{\prime \prime}, \mathrm{Ar}\right) ; 127.88(\mathrm{C}-2$, $=\underline{\mathrm{C}}-\mathrm{CO}, \mathrm{Ar}) ; 128.79$ (C-3", Ar); 130.66 (C-1", Ar); 132.89 $(=\mathrm{C}) ; 139.36\left(\mathrm{C}-4^{\prime \prime}, \mathrm{Ar}\right) ; 159.08(\mathrm{NH}-\mathrm{C}=\mathrm{O}) ; 161.70$ (C$\left.4^{\prime}, \mathrm{C}=\mathrm{O}\right) ; 164.43$ (NNHC=O); $191.14\left(\mathrm{C}-2^{\prime}, \mathrm{C}=\mathrm{S}\right)$. HRMS, $m / z: 578.8774$ found (calculated for $\mathrm{C}_{18} \mathrm{H}_{14} \mathrm{~N}_{4} \mathrm{O}_{4}^{79} \mathrm{Br}_{2} \mathrm{NaS}_{2}$ $[\mathrm{M}+\mathrm{Na}]^{+}$requires 578.8772$)$.
4,5-Dibromo-1H-pyrrol-2-carboxylic acid \{3-[3-(4methoxy-benzoylamino)-4-oxo-2-thioxo-thiazolidin-5ylidene-propyl\}-amide (3h)

Compound $\mathbf{3 h}$ was prepared in $74 \%$ yield $(154 \mathrm{mg})$ from 4,5-dibromo- $1 \mathrm{H}$-pyrrole-2-carboxylic acid (3-oxo-propyl)amide 1a (115 mg, $0.35 \mathrm{mmol})$, 4-methoxy- $N$-(4-oxo-2thioxo-thiazolidin-3-yl)-benzamide $2 \mathrm{~g}(100 \mathrm{mg}, 0.35 \mathrm{mmol})$, sodium acetate $\mathrm{AcONa}(29 \mathrm{mg}, 0.35 \mathrm{mmol})$ in glacial acetic acid (130 $\mu \mathrm{L}, 2.33 \mathrm{mmol}, 6.58$ equiv.) according to the standard procedure. $\mathrm{Mp}=190{ }^{\circ} \mathrm{C}$ (decomposition). ${ }^{1} \mathrm{H}$ NMR (DMSO- $\left.d_{6}\right) \delta: 2.53\left(\mathrm{~m}, 2 \mathrm{H}, \mathrm{CH}_{2} \mathrm{CH}=\right) ; 3.45$ $\left(\mathrm{m}, 2 \mathrm{H}, \mathrm{NC}_{2}\right) ; 3.84\left(\mathrm{~s}, 3 \mathrm{H}, \mathrm{C}_{3} \mathrm{O}\right) ; 6.89(\mathrm{~d}, 1 \mathrm{H}, J=$ $2.6 \mathrm{HZ}, \mathrm{H}-3,=\mathrm{C} \underline{\mathrm{H}}, \mathrm{Ar}) ; 7.09$ (m, 2H, H-3", Ar); 7.18 $(\mathrm{t}, 1 \mathrm{H}, J=7.7 \mathrm{~Hz}, \mathrm{C}=\mathrm{C} \underline{\mathrm{H}}) ; 7.91\left(\mathrm{~m}, 2 \mathrm{H}, \mathrm{H}-2^{\prime \prime}, \mathrm{Ar}\right)$; $8.38(\mathrm{t}, 1 \mathrm{H}, J=5.5 \mathrm{~Hz}, 1 \mathrm{H}, \mathrm{NHCO}) ; 11.53(\mathrm{~s}, 1 \mathrm{H}$, $\mathrm{NN} \underline{\mathrm{HCO}}$ ); 12.73 (br s, $1 \mathrm{H}, \mathrm{N} \underline{\mathrm{H}}, \mathrm{Ar}$ ). ${ }^{13} \mathrm{C}$ NMR (DMSO$\left.d_{6}\right) \delta: 31.95\left(\underline{\mathrm{CH}}_{2} \mathrm{CH}=\right) ; 36.74\left(\mathrm{NCH}_{2}\right) ; 55.49\left(\underline{\mathrm{CH}}_{3} \mathrm{O}\right)$; $97.81(\mathrm{C}-4,=\underline{\mathrm{CBr}}, \mathrm{Ar}) ; 104.76(\mathrm{C}-5,=\underline{\mathrm{CBr}}, \mathrm{Ar}) ; 112.60$ $(\mathrm{C}-3,=\mathrm{CH}, \mathrm{Ar}) ; 114.03$ (C-3", Ar); 114.82 (C-3", $\mathrm{Ar})$; $122.70\left(\mathrm{C}-5^{\prime},=\underline{\mathrm{C}}\right) ; 123.90(\mathrm{C}-2,=\mathrm{C}-\mathrm{CO}, \mathrm{Ar}) ; 127.81(\mathrm{C}-$ $\left.2^{\prime \prime}, \mathrm{Ar}\right) ; 129.80$ (C-2", Ar); 139.21 ( $\left.\underline{\mathrm{CH}}=\right)$; 159.09 (C-1", $\mathrm{Ar}) ; 160.55$ (C-4", Ar); 162.77 (NH- $\underline{\mathrm{C}}=\mathrm{O}) ; 163.84\left(\mathrm{C}-4^{\prime}\right.$, $\underline{\mathrm{C}}=\mathrm{O}) ; 166.31 \quad(\mathrm{NNHC}=\mathrm{O}) ; 196.11 \quad\left(\mathrm{C}-2^{\prime}, \underline{\mathrm{C}}=\mathrm{S}\right)$. HRMS, $m / z: 608.8875$ found (calculated for $\mathrm{C}_{20} \mathrm{H}_{20} \mathrm{~N}_{4} \mathrm{O}_{5}^{79} \mathrm{Br}_{2} \mathrm{NaS}_{2}$ $[\mathrm{M}+\mathrm{Na}]^{+}$requires 608.8874$)$.

4,5-Dibromo-1H-pyrrol-2-carboxylic acid [3-(4-oxo-3phenylacetylamino-2-thioxo-thiazolidin-5-ylidene)-propyl]amide (3i)

Compound $3 \mathbf{i}\left(R_{f} 0.71\right)$ was prepared in $58 \%$ yield (126 $\mathrm{mg}$ ) from 4,5-dibromo-1 $H$-pyrrole-2-carboxylic acid (3oxo-propyl)-amide $1 \mathrm{a}(122 \mathrm{mg}, 0.38 \mathrm{mmol}), \mathrm{N}$-(4-oxo2-thioxo-thiazolidin-3-yl)-2-phenyl-acetamide $\mathbf{2 h}$ (100 mg, $0.38 \mathrm{mmol})$, sodium acetate $\mathrm{AcONa}(31 \mathrm{mg}, 0.38 \mathrm{mmol})$ in glacial acetic acid $(140 \mu \mathrm{L}, 2.47 \mathrm{mmol}, 6.58$ equiv. $)$ according to the standard procedure. $\mathrm{Mp}=100{ }^{\circ} \mathrm{C}$ (decomposition). ${ }^{1} \mathrm{H}$ NMR (DMSO- $\left.d_{6}\right) \delta: 2.53\left(\mathrm{~m}, 2 \mathrm{H}, \mathrm{C}_{2} \mathrm{CH}=\right.$ ); $3.43\left(\mathrm{~m}, 2 \mathrm{H}, \mathrm{NC}_{2}\right) ; 3.66$ (s, 2H, $\left.\mathrm{C}_{2} \mathrm{CONH}\right) ; 6.87$ (d, $1 \mathrm{H}, J=2.7 \mathrm{~Hz},=\mathrm{C} \underline{\mathrm{H}}, \mathrm{Ar}) ; 7.12(\mathrm{t}, 1 \mathrm{H}, J=7.6 \mathrm{~Hz}$, $\mathrm{C}=\mathrm{C} \underline{\mathrm{H}}) ; 7.29-7.33$ (m, 5H, H-2", H-3", H-4", $\mathrm{Ar}) ; 8.36$ (t, $1 \mathrm{H}, J=5.9 \mathrm{~Hz}, \mathrm{~N} \underline{\mathrm{HCO}}) ; 11.36(\mathrm{~s}, 1 \mathrm{H}, \mathrm{NN} \underline{\mathrm{HCO}})$; 12.71 (br s, $1 \mathrm{H}, \mathrm{N} \underline{\mathrm{H}}, \mathrm{Ar}){ }^{13} \mathrm{C}$ NMR (DMSO- $d_{6}$ ) $\delta: 28.98$ $\left(\mathrm{CH}_{2} \mathrm{CH}=\right) ; 31.89\left(\mathrm{NHCOCH}_{2}\right) ; 36.74\left(\mathrm{NCH}_{2}\right) ; 97.81(\mathrm{C}-$ 4, $=\mathrm{CBr}, \mathrm{Ar}) ; 104.74\left(\mathrm{C}-5^{\prime}, \underline{\mathrm{C}}=\mathrm{CH}\right) ; 122.62(\mathrm{C}-3,=\underline{\mathrm{CH}}$, Ar); 123.98 (C-5, =CBr, Ar); $126.72\left(\mathrm{C}-4^{\prime \prime}, \mathrm{Ar}\right) ; 127.87$ (=C-CO, Ar); 128.26 (C-3", Ar); 129.11 (C-2" , Ar); 134.53 (C-1", $\mathrm{Ar}) ; 138.81(\mathrm{C}=\mathrm{CH}) ; 159.08(\mathrm{NH}-\mathrm{C}=\mathrm{O}) ; 161.53$ (C$\left.4^{\prime}, \mathrm{C}=\mathrm{O}\right) ; 168.53(\mathrm{NNHC}=\mathrm{O}) ; 190.99\left(\mathrm{C}-2^{\prime}, \mathrm{C}=\mathrm{S}\right)$. HRMS, $m / z: 592.8927$ found (calculated for $\mathrm{C}_{19} \mathrm{H}_{16} \mathrm{~N}_{4} \mathrm{O}_{3}^{79} \mathrm{Br}_{2} \mathrm{NaS}_{2}$ $[\mathrm{M}+\mathrm{Na}]^{+}$requires 592.8928). 
4,5-Dibromo-1H-pyrrol-2-carboxylic acid \{3-[4-oxo-3(3-phenyl-propionylamino)-2-thioxo-thiazolidin-5-ylidene]propyl\}-amide (3j)

Compound $3 \mathbf{j}\left(R_{f}\right.$ 0.77) was prepared in $49 \%$ yield (46 $\mathrm{mg}$ ) from 4,5-dibromo- $1 H$-pyrrole-2-carboxylic acid (3oxo-propyl)-amide 1a $(52 \mathrm{mg}, 0.16 \mathrm{mmol}), \mathrm{N}$-(4-oxo-2thioxo-thiazolidin-3-yl)-3-phenyl-propionamide $2 \mathbf{i}$ (45 mg, $0.16 \mathrm{mmol})$, sodium acetate $\mathrm{AcONa}(14 \mathrm{mg}, 0.16 \mathrm{mmol})$ in glacial acetic acid $(61 \mu \mathrm{L}, 1.06 \mathrm{mmol}, 6.58$ equiv.) according to the standard procedure. $\mathrm{Mp}=100{ }^{\circ} \mathrm{C}$ (decomposition). ${ }^{1} \mathrm{H}$ NMR (DMSO- $\left.d_{6}\right) \delta: 2.62\left(\mathrm{~m}, 2 \mathrm{H}, \mathrm{CH}_{2} \mathrm{CO}\right) ; 2.88$ $\left(\mathrm{m}, 2 \mathrm{H}, \underline{\mathrm{C}}_{2} \mathrm{Ar}\right) ; 3.43\left(\mathrm{~m}, 2 \mathrm{H}, \mathrm{NC}_{2}\right) ; 6.88(\mathrm{~d}, 1 \mathrm{H}, J=$ $2.5 \mathrm{~Hz},=\underline{\mathrm{C}}, \mathrm{Ar}) ; 7.13(\mathrm{t}, 1 \mathrm{H}, J=7.6 \mathrm{~Hz}, \mathrm{C}=\mathrm{C} \underline{\mathrm{H}}) ; 7.23-$ 7.31 (m, 5H, H-2" $\left., \mathrm{H}-3^{\prime \prime}, \mathrm{H}-4^{\prime \prime}, \mathrm{Ar}\right) ; 8.36$ (t, $1 \mathrm{H}, J=5.9$ $\mathrm{Hz}, \mathrm{NHCO}) ; 11.15$ (s, 1H, NNHCO); 12.72 (br s, 1H, H-

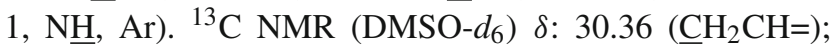
$31.87\left(\underline{\mathrm{CH}}_{2} \mathrm{Ar}\right) ; 34.45\left(\underline{\mathrm{CH}}_{2} \mathrm{CO}\right) ; 36.75\left(\mathrm{NHCH}_{2}\right) ; 97.79$ (C4, =ㅡㄹ, Ar); $104.74(\mathrm{C}-5,=\underline{\mathrm{CBr}}, \mathrm{Ar}) ; 112.60(\mathrm{C}-3,=\underline{\mathrm{CH}}$, $\mathrm{Ar}) ; 123.99\left(\mathrm{C}-5^{\prime}, \mathrm{C}=\mathrm{CH}\right) ; 126.04\left(\mathrm{C}-4^{\prime \prime}, \mathrm{Ar}\right) ; 127.87(\mathrm{C}-2$, $=\underline{\mathrm{CCO}}, \mathrm{Ar}) ; 128.23$ (C-2", $\mathrm{Ar}) ; 128.28$ (C-3", $\mathrm{Ar}) ; 138.73$ $(=\underline{\mathrm{CH}}) ; 140.45$ (C-1", Ar); $159.07(\mathrm{NH}-\underline{\mathrm{C}}=\mathrm{O}) ; 161.58$ (C$\left.4^{\prime}, \underline{\mathrm{C}}=\mathrm{O}\right) ; 169.91$ (NNHC$\left.=\mathrm{O}\right) ; 191.02\left(\mathrm{C}-2^{\prime}, \underline{\mathrm{C}}=\mathrm{S}\right)$. HRMS, $m / z$ : 606.9084 found (calculated for $\mathrm{C}_{20} \mathrm{H}_{18} \mathrm{~N}_{4} \mathrm{O}_{3}^{79} \mathrm{Br}_{2} \mathrm{NaS}_{2}$ $[\mathrm{M}+\mathrm{Na}]^{+}$requires 606.9085).

$\mathrm{X}$-ray crystallographic data for 4,5-dibromo- $1 \mathrm{H}$ pyrrol-2-carboxylic acid [3-(4-oxo-2-thioxothiazolidin-5-ylidene)-propyl]-amide (3a)

$\left(2\left(\mathrm{C}_{11} \mathrm{H}_{9} \mathrm{Br}_{2} \mathrm{~N}_{3} \mathrm{O}_{2} \mathrm{~S}_{2}\right)\right) ; M=878.3$. APEXII, BrukerAXS diffractometer, Mo-K $\alpha$ radiation $(\lambda=0.71073 \AA)$, $T=150(2) \mathrm{K}$; triclinic $P$-1 (I.T.\#2), $a=7.0648(6), b=$ 14.9877(13), $c=17.6708(13) \AA, \alpha=75.216(3), \beta=$ 87.475(3), $\gamma=78.233(3)^{\circ}, V=1771.1(3) \AA^{3}, Z=2, d=$ $1.647 \mathrm{~g} \mathrm{~cm}^{-3}, \mu=4.815 \mathrm{~mm}^{-1}$. The structure was solved by direct methods using the SIR 97 program [46], and then refined with full-matrix least-square methods based on $F^{2}$ (SHELXL-97) [47] with the aid of the WINGX [48]program. The contribution of the disordered solvents to the calculated structure factors was estimated following the BYPASS algorithm [49], implemented as the SQUEEZE option in PLATON [50]. A new data set, free of solvent contribution, was then used in the final refinement. All non-hydrogen atoms were refined with anisotropic atomic displacement parameters. $\mathrm{H}$ atoms were finally included in their calculated positions. A final refinement on $F^{2}$ with 8064 unique intensities and 361 parameters converged at $\omega R\left(F^{2}\right)=0.2134(R(F)=0.0795)$ for 2888 observed reflections with $I>2 \sigma(I)$. Crystallographic data for the structure of $\mathbf{3 a}$ in this paper have been deposited in the Cambridge Crystallographic Data Centre as supplementary publication number CCDC 938832. Copies of the data can be obtained, free of charge, on application to CCDC, 12 Union Road, Cambridge CB21EZ, UK [fax: +44-0-1223-336033 or e-mail:deposit@ccdc.cam.ac.uk].

Biochemistry part

Protein kinase assay buffers

Buffer A $10 \mathrm{mM} \mathrm{MgCl} 2,1 \mathrm{mM}$ EGTA, $1 \mathrm{mM}$ DTT, $25 \mathrm{mM}$ Tris-HCl pH 7.5, $50 \mu \mathrm{g}$ heparin $/ \mathrm{mL}$. Buffer $B 50 \mathrm{mM} \mathrm{MgCl}_{2}$, $90 \mathrm{mM} \mathrm{NaCl}, 30 \mathrm{mM}$ Tris- $\mathrm{HCl} \mathrm{pH} 7.4$.

\section{Kinase preparations and assays}

Kinase activities for each enzyme were assayed in buffer A or $\mathrm{B}$, with their corresponding substrates, in the presence of $15 \mu \mathrm{M}$ ATP in a final volume of $30 \mu \mathrm{L}$. After 30-min incubation at $30{ }^{\circ} \mathrm{C}$, the reaction was stopped by harvesting, using a FilterMate harvester (Packard), onto P81 phosphocellulose papers (GE Healthcare) which were washed in $1 \%$ phosphoric acid. Scintillation fluid was added and the radioactivity measured in a Packard counter. Blank values were subtracted and activities calculated as pmoles of phosphate incorporated during the 30-min incubation. The activities were expressed in $\%$ of the maximal activity, i.e., in the absence of inhibitors. Controls were performed with appropriate dilutions of DMSO.

CDK1/cyclin B (M phase starfish oocytes, native), CDK2/ cyclin $E$ (human, recombinant, from A. Echalier), and CDK5/p25 (human, recombinant, expressed in E. coli) [51] were assayed in Buffer A (supplemented extemporaneously with $0.15 \mathrm{mg} \mathrm{BSA} / \mathrm{mL}$, except for CDK2) with $25 \mu \mathrm{g}$ of histone $\mathrm{H} 1$.

DYRK1A (rat, recombinant, expressed in E. coli as GST fusion protein, provided by Dr. W. Becker), DYRK1A (human, recombinant, expressed in E. coli as GST fusion proteins), DYRK4 (human, recombinant, expressed in insect cells), CLK1, 2, 3, and 4 (mouse, recombinant, expressed in E. coli as GST fusion proteins) was assayed as described for CDK1/cyclin B with $1 \mu \mathrm{g}$ of RS peptide (GRSRSRSRSRSR) as a substrate. Native DYRK1A was purified from rat brain, taking advantage of the natural poly-histidine sequence located in the C-terminal domain of DYRK1A, by affinity chromatography on cobalt-sepharose beads (Clontech). Briefly, after a 30 -min preclearing incubation at $4{ }^{\circ} \mathrm{C}$ with sepharose beads, rat brain lysates were incubated with cobaltsepharose beads ( $400 \mu \mathrm{g}$ total proteins $/ 20 \mu \mathrm{L}$ beads). Kinase activity of native DYRK1A was directly assessed on the beads in buffer A $(+0.5 \mathrm{mg} \mathrm{BSA} / \mathrm{mL})$ using the Woodtide substrate (KKISGRLSPIMTEQ).

$G S K-3 \alpha / \beta$ (porcine brain, native, affinity purified on axin-sepharose beads), GSK-3 $\alpha$ and GSK3 $\beta$ (human, recombinant, expressed in insect cells) and PfGSK-3 (Plasmodium falciparum, recombinant, expressed in E. coli) were assayed 
as described for CDK1/cyclin B, but using a GSK-3 specific substrate (GS-1: YRRAAVPPSPSLSRHSSPHQpSEDEEE, where $\mathrm{pS}$ stands for phosphorylated serine) [52].

Casein kinase $1(C K 1 \delta / \varepsilon)$ (porcine brain, native) was assayed with $0.67 \mu \mathrm{g}$ of CKS peptide (RRKHAAIGpSAYSITA), a CK1 specific substrate [53].

CLK1 (mouse, recombinant, expressed in E. coli as GST fusion proteins) was assayed in buffer $\mathrm{A}(+0.15 \mathrm{mg} \mathrm{BSA} / \mathrm{mL})$ with RS peptide (GRSRSRSRSRSR) ( $1 \mu \mathrm{g} /$ assay).

Acknowledgments One of us (S.G.) wishes to thank the "Ministère de la Recherche et de l'Enseignement Supérieur" for research fellowships. Financial support of this program carried out under the French National Cancer Institute "Cancéropôle Grand Ouest" by contracts PRIR 048390 and ACI 04-2254, is gratefully acknowledged.

\section{References}

1. Hotta N, Akanuma Y, Kawamori R, Matsuoka K, Oka Y, Shichiri M, Toyota T, Nakashima M, Yoshimura I, Sakamoto N, Shigeta Y (2006) Long-term clinical effects of Epalrestat, an aldose reductase inhibitor, on diabetic peripheral neuropathy. Diabetes Care 29:1538-1544. doi:10.2337/dc05-2370

2. El-Kabbani Ruiz F, Darmanim C, Chung RP-T (2004) Aldose reductase structures: implications for mechanism and inhibition. Cell Mol Life Sci 61:750-752. doi:10.1007/s00018-003-3403-2

3. Heng S, Tieu W, Hautmann S, Kuan K, Pedersen DS, Pietsch M, Güutschow M, Abell AD (2011) New cholesterol esterase inhibitors based on rhodanine and thiazolidinedione scaffolds. Bioorg Med Chem 19:7453-7463. doi:10.1016/j.bmc.2011.10.042

4. Degterev A, Lugovskoy A, Cardone M, Mulley B, Wagner G, Mitchison T, Yuan J (2001) Identification of small-molecule inhibitors of interaction between the $\mathrm{BH} 3$ domain and $\mathrm{Bcl}-\mathrm{x}_{L}$. Nat Cell Biol 3:173-182. doi:10.1038/35055085

5. Wang L, Kong F, Kokoski CL, Andrews DW, Xing C (2008) Development of dimeric modulators for anti-apoptotic $\mathrm{Bcl}-2$ proteins. Bioorg Med Chem Lett 18:236-240. doi:10.1016/j.bmcl.2007.10. 088

6. Summerer D, Rudinger N-Z, Ilka Detmer I, Marx A (2005) Enhanced fidelity in mismatch extension by DNA polymerase through directed combinatorial enzyme design. Angew Chem Int Ed 44:4712-4715. doi:10.1002/anie.200500047

7. Strittmatter T, Bareth B, Immel TA, Huhn T, Mayer TU, Marx A (2011) Small molecule inhibitors of human DNA polymerase $\lambda$. Chem Biol 6:314-319. doi:10.1021/cb100382m

8. Bulic B, Pickhardt M, Schmidt B, Mandelkow EM, Waldmann H, Mandelkow E (2009) Development of tau aggregation inhibitors for Alzheimer's disease. Angew Chem Int Ed 48:1740-1752. doi:10. 1002/anie.200802621

9. Bulic B, Pickhardt M, Mandelkow EM, Mandelkow E (2010) Tau protein and tau aggregation inhibitors. Neuropharmacology 59:276-289. doi:10.1016/j.neuropharm.2010.01.016

10. Mishra R, Bulic B, Sellin D, Jha S, Waldmann H, Winter R (2008) Small-molecule inhibitors of islet amyloid polypeptide fibril formation. Angew Chem Int Ed 47:4679-4682. doi:10.1002/anie. 200705372

11. Whitesitt C-A, Simon R-L, Reel J-K, Sigmund S-K, Phillips M-L, Shadle J-K, Heinz L-J, Koppel G-A, Hunden D-C, Lifer S-L, Berry D, Ray J, Little S-P, Liu X, Marshall W-S, Panetta J-A (1996) Synthesis and structure-activity relationships of benzophenones as inhibitors of cathepsin D. Bioorg Med Chem Lett 6:2157-2162. doi:10.1016/0960-0894X(96)00393-9
12. Kumar G, Parasuraman P, Sharma SK, Banerjee T, Karmodiya K, Surolia N, Surolia A (2007) Discovery of a rhodanine class of compounds as inhibitors of Plasmodium falciparum enoyl-acyl carrier protein reductase. J Med Chem 50:2665-2675. doi:10.1021/ jm061257w

13. Soltero-Higgin M, Carlson E-E, Phillips J-H, Kiessling L-L (2004) Identification of inhibitors for UDP-galactopyranose mutase. J Am Chem Soc 126:10532-10533. doi:10.1021/ja048017v

14. Powers J-P, Piper D-E, Li Y, Mayorga V, Anzola J, Chen J-M, Jaen J-C, Lee G, Liu J, Peterson M-G, Tonn G-R, Ye Q, Walker NPC, Wang Z (2006) SAR and mode of action of novel non-nucleoside inhibitors of hepatitis C NS5b RNA polymerase. J Med Chem 49:1034-1046. doi:10.1021/jm050859x

15. Rajamaki S, Innitzer A, Falciani C, Tintori C, Christ F, Witvrouw M, Debyser Z, Massa S, Botta M (2009) Exploration of novel thiobarbituric acid-, rhodanine- and thiohydantoin-based HIV-1 integrase inhibitors. Bioorg Med Chem Lett 19:3615-3618. doi:10. 1016/j.bmcl.2009.04.132

16. Dayam R, Sanchez T, Neamati N (2005) $\beta$-Diketo acid pharmacophore. 1. Discovery of structurally diverse inhibitors of HIV1 integrase inhibitors. J Med Chem 48:111-120. doi:10.1021/ jm0496077

17. Kodimuthali A, Jabaris SSL, Pal M (2008) Recent advances on phosphodiesterase 4 inhibitors for the treatment of asthma and chronic obstructive pulmonary disease. J Med Chem 51:54715885. doi:10.1021/jm800582j

18. Sherida L, Johnson SL, Chen L-H, Harbach R, Sabet M, Savinov A, Cotton NJH, Strongin A, Guiney D, Pellecchia M (2008) Rhodanine derivatives as selective protease inhibitors against bacterial toxins. Chem Biol Drug Des 71:131-139. doi:10.1111/j. 1747-0285.2007.00617.x

19. Bazureau J-P, Carreaux F, Renault S, Meijer L, Lozach O, Patent WO 2009/05032 A2, 23 April 2009. Demande PCT/FR 2008/001152, 01 October 2008

20. Debdab M, Renault S, Lozach O, Meijer L, Paquin L, Carreaux F, Bazureau J-P (2010) Synthesis and preliminary biological evaluation of new derivatives of the marine alkaloid leucettamine $B$ as kinase inhibitors. Eur J Med Chem 45:805-810. doi:10.1016/j. ejmech.2009.10.009

21. Debdab M, Carreaux F, Renault S, Soundararajan M, Federov O, Lozach O, Babault L, Baratte B, Ogawa Y, Hagiwara M, Einsenreich A, Rauch U, Knapp S, Meijer L, Bazureau J-P (2011) Leucettines, a class of potent inhibitors of cdc2-like kinases and dual specificity, tyrosine phosphorylation regulated kinases derived from the marine sponge leucettamine B: modulation of alternative pre-RNA splicing. J Med Chem 54:4172-4186. doi:10.1021/ jm200274d

22. Tahtouh T, Federov O, Soundararajan M, Burgy G, Durieu E, Lozach O, Cochet C, Schmid R-S, Lo D-C, Delhommel F, Oberholzer A-E, Pearl L-H, Carreaux F, Bazureau J-P, Knapp S, Meijer L (2012) Selectivity, cocrystal structures, and neuroprotective properties of leucettines, a family of protein kinase inhibitors derived from the marine sponge alkaloid leucettamine B. J Med Chem 55:9312-9330. doi:10.1021/jm301034u

23. Burgy G, Tahtouh T, Durieu E, Josselin-Foll B, Limanton E, Meijer L, Carreaux F, Bazureau J-P (2013) Chemical synthesis and biological validation of immobilized protein kinase inhibitory leucettines. Eur J Med Chem 62:728-737. doi:10.1016/j.ejmech.2013.01.035

24. Cafieri F, Fattorusso E, Mangoni A, Taglialatela-Scafati O (1996) Dispacamides, anti-Histamine alkaloids from Caribbean Agelas Sponges. Tetrahedron Lett 37:3587-3590. doi:10.1016/ 0040-4039(96)00629-6

25. Guiheneuf S, Paquin L, Carreaux F, Durieu E, Meijer L, Bazureau JP (2012) An efficient approach to dispacamide A and its derivatives. Org Biomol Chem 10:978-987. doi:10.1039/c1ob06161e 
26. Guiheneuf S, Paquin L, Carreaux F, Durieu E, Meijer L, Bazureau $\mathrm{J}-\mathrm{P}$ (unpublished results)

27. de la Hoz A, Loupy A (eds) (2012) Microwave in organic synthesis. Wiley-VCH, Weinheim. ISBN 978-3-527-33116-1

28. Bazureau J-P, Draye M (eds) (2011) Ultrasound and microwave: recent advances in organic chemistry. Research Signpost, Kerala. ISBN 978-81-7895-532-2

29. Radi M, Botta M, Falchi F, Maga G, Baldanti F, Paolucci S, Patent WO 2011/039735, 07 April 2011. Demande PCT/IT 2010/054475, 04 October 2010

30. Kamila S, Biehl ER (2012) Microwave-assisted synthesis of novel bis(2-thioxothiazolidin-4-one) derivatives as potential GSK3 inhibitors. Tetrahedron Lett 53:3998-4003. doi:10.1016/j.tetlet. 2012.05.088

31. Nitsche C, Klein CD (2012) Aqueous microwave-assisted one-pot synthesis of $N$-substituted rhodanines. Tetrahedron Lett 53:51975201. doi:10.1016/j.tetlet.2012.07.002

32. Heng S, Tieu W, Hautmann S, Kuan K, Pedersen DS, Pietsch M, Gütschow M, Abell AD (2011) New cholesterol esterase inhibitors based on rhodanine and thiazolidinedione scaffolds. Bioorg Med Chem 19:7453-7463. doi:10.1016/j.bmc.2011.10.042

33. Safonov I-G, Heerding D-A, Keenan R-M, Price A-T, EricksonMuller C-L, Hopson C-B, Levin J-L, Lord K-A, Tapley P-M (2006) New benzimidazoles as thrombopoietin receptor agonists. Bioorg Med Chem Lett 16:1212-1216. doi:10.1016/j.bmcl.2005.11.096

34. Tomašić T, Zidar N, Rupnik V, Kovač A, Blanot D, Gobec S, Kikelj D, Mašič LP (2009) Synthesis and biological evaluation of new glutamic acid-based inhibitors of MurD ligase. Bioorg Med Chem Lett 19:153-157. doi:10.1016/j.bmcl.2008.10.129

35. Tomašić T, Zidar N, Mueller-Premru M, Kikelj D, Mašič LP (2010) Synthesis and antibacterial activity of 5-ylidenethiazolidin4-ones and 5-benzylidene-4,6-pyrimidinediones. Eur J Med Chem 45:1667-1672. doi:10.1016/j.ejmech.2009.12.030

36. Zidar N, Tomasic T, Sink R, Rupnik V, Kovac A, Turk S, Patin D, Blanot D, Contreras Martel C, Dessen A, Mueller-Premru M, Zega A, Gobec S, Peterlin Masic L, Kikelj D (2010) Discovery of novel 5-benzylidenerhodanine and 5-benzylidenethiazolidine2,4-dione inhibitors of MurD ligase. J Med Chem 53:6584-6594. doi: $10.1021 / \mathrm{jm} 100285 \mathrm{~g}$

37. Zidar N, Tomašić T, Šink R, Kovač A, Patin D, Blanot D, ContrerasMartel C, Dessen A, Mueller-Premru M, Zega A, Gobec S, Mašič LP, Kikelj D (2011) New 5-benzylidenethiazolidin-4-one inhibitors of bacterial MurD ligase: design, synthesis, crystal structures, and biological evaluation. Eur J Med Chem 46:5512-5523. doi:10. 1016/j.ejmech.2011.09.017

38. Chen H, Fan Y-H, Natarajan A, Guo Y, Iyasere J, Harbinski F, Luis L, Christ W, Aktas H, Halperin J (2004) Synthesis and biological evaluation of thiazolidine-2,4-dione and 2,4-thione derivatives as inhibitors of translation initiation. Bioorg Med Chem Lett 14:54015405. doi:10.1016/j.bmcl.2004.08.017

39. Whitesitt CA, Simon RL, Reel Jon K, Sigmund SK, Phillips ML, Shadle JK, Heinz LJ, Koppel GA, Hundel DC, Lifer SL, Berry D, Ray J, Little SP, Liu X, Marshall W (1996) Synthesis and structure-activity relationships of benzophenones as inhibitors of cathepsin D. Bioorg Med Chem Lett 6:2157-2162.doi:10.1016/ 0960-894X(96)00393-9
40. Lee B, Jung ME, Wolf MC, Zhang T, Patent WO 2010/044924, 22 April 2010. Demande PCT/US 2009/047854, 18 June 2009

41. Opletalova V, Dolezel J, Kralova K, Pesko M, Kunes J, Jampilek J (2011) Synthesis and characterization of (Z)-5arylmethylidenerhodanines with photosynthesis-inhibiting properties. Molecules 16:5207-5227. doi:10.3390/molecules16065207

42. Alizadeh A, Khodaei MM, Eshghi A (2010) A solvent-free protocol for the green synthesis of arylalkylidene rhodanines in a task-specific ionic liquid. Can J Chem 88:514-518. doi:10.1139/ V10-011

43. Gong K, He ZW, Xu Y, Fang D, Liu Z-L (2008) Green synthesis of 5-benzylidene rhodanine derivatives catalyzed by 1-butyl-3methyl imidazolium hydroxide in water. Monatsh Chem 139:913915. doi:10.1007/s00706-008-0871-y

44. Ben-Alloum A, Bakkas S, Bougrin K, Soufiaoui M (1998) Synthèse de nouvelles spiro-rhodanine-pyrazolines par addition dipolaire1,3 de la diphenylnitrilimine sur quelques 5 -arylidènerhodanines en "milieu sec" et sous irradiation micro-onde. New J Chem 22:809_ 812. doi:10.1039/A803447H

45. Sing WT, Lee CL, Yeo SL, Lim SP, Sim MM (2001) Arylalkylidene rhodanine with bulky and hydrophobic functional group as selective HCV NS3 protease inhibitor. Bioorg Med Chem Lett 11:91-94. doi:10.1016/S0960-894X(00)00610-7

46. Altomare A, Burla MC, Camalli M, Cascarano G, Giacovazzo C, Guagliardi A, Moliterni AGG, Polidori G, Spagna R (1999) SIR97: a new tool for crystal structure determination and refinement. J Appl Cryst 32:115-119. doi:10.1107/S0021889898007717

47. Sheldrick GM (2008) A short history of SHELX. Acta Cryst A64:112-122. doi:10.1107/S0108767307043930

48. Farrugia LJ (1999) WinGX suite for small-molecule singlecrystal crystallography. J Appl Cryst 32:837-838. doi:10.1107/ S0021889899006020

49. van der Sluis P, Spek AL (1990) BYPASS: an effective method for the refinement of crystal structures containing disordered solvent regions. Acta Cryst A46:194-201. doi:10.1107/ S0108767389011189

50. Spek AL (2003) Single-crystal structure validation with the program PLATON. J Appl Cryst 36:7-13. doi:10.107/ S0021889802022112

51. Leclerc S, Garnier M, Hoessel R, Marko D, Bibb JA, Snyder GL, Greengard P, Biernat J, Mandelkow E-M, Eisenbrand G, Meijer L (2001) Indirubins inhibit glycogen synthase kinase- $3 \beta$ and CDK5/P25, two protein kinases involved in abnormal tau phosphorylation in Alzheimer's disease: a property common to most cyclin-dependant kinase inhibitors? J Biol Chem 276:251-260. doi:10.1074/jbc.M002466200

52. Primot A, Baratte B, Gompel M, Borgne A, Liabeuf S, Romette JL, Costantini F, Meijer L (2000) Purification of GSK-3 by affinity chromatography on immobilized axin. Protein Expr Purif 20:394404. doi:10.1006/prep.2000.1321

53. Reinhardt J, Ferandin Y, Meijer L (2007) Purification of CK1 by affinity chromatography on immobilised axin. Protein Expr Purif 54:101-109. doi:10.1016/j.pep.2007.02.020 